\title{
OECDpublishing
}

\section{AGRICULTURE, FOOD AND JOBS IN WEST AFRICA}

\section{WEST AFRICAN PAPERS}

April 2018 No. 14

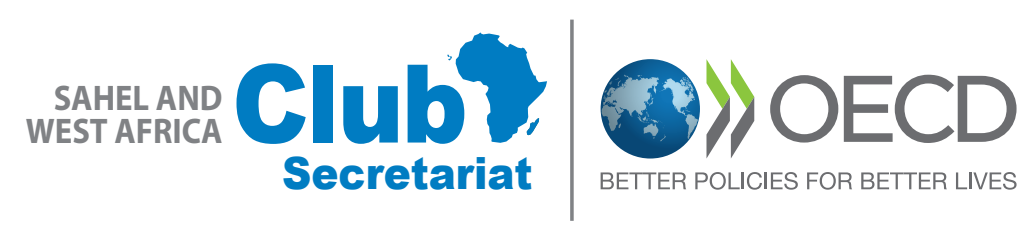





\section{AGRICULTURE, FOOD AND JOBS IN WEST AFRICA}

This paper has been prepared by

THOMAS ALLEN

PHILIPP HEINRIGS

INHOI HEO

Sahel and West Africa Club Secretariat

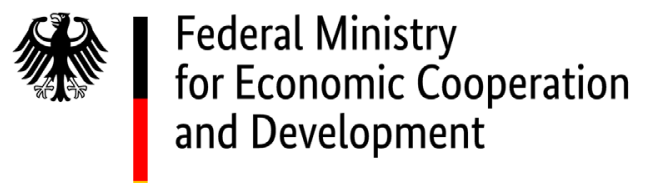




\section{WEST AFRICAN PAPERS}

The West African Papers series explores African socio-economic, political and security dynamics from a regional and multidisciplinary perspective. It seeks to stimulate discussion and gather information to better anticipate the changes that will shape future policies. The series is designed for a wide audience of specialists, development practitioners, decision makers and the informed public. Papers are available in English and/or French, and summaries are available in both languages. Initiated by the Sahel and West Africa Club (SWAC) to highlight and promote West African issues, the work presented is prepared by its Secretariat, Members and partners, other OECD departments, related international organisations, associated experts and researchers.

Please cite this publication as:

Allen, T., P. Heinrigs and I. Heo (2018), "Agriculture, food and jobs in West Africa", West African Papers, $\mathrm{N}^{\circ} 14$, OECD Publishing, Paris.

https://doi.org/10.1787/dc152bc0-en

Authors' contact: thomas.allen@oecd.org, philipp.heinrigs@oecd.org, inhoi.heo@oecd.org

ISSN 2414-2026

OECD Working Papers should not be reported as representing the official views of the OECD or of its member countries. The opinions expressed and arguments employed are those of the authors.

This document and any map included herein are without prejudice to the status of or sovereignty over any territory, to the delimitation of international frontiers and boundaries and to the name of any territory, city or area.

Working Papers describe preliminary results or research in progress by the author(s) and are published to stimulate discussion on a broad range of issues on which the OECD works. Comments on Working Papers are welcomed, and may be sent to the Sahel and West Africa Club, OECD, 2 rue André-Pascal, 75775 Paris Cedex 16, France.

Authorised for publication by Laurent Bossard, Director, Sahel and West Africa Club Secretariat (SWAC/OECD).

You can copy, download or print OECD content for your own use, and you can include excerpts from OECD publications, databases and multimedia products in your own documents, presentations, blogs, websites and teaching materials, provided that suitable acknowledgment of OECD as source and copyright owner is given. All requests for commercial use and translation rights should be submitted to rights@oecd.org. 


\begin{abstract}
The food economy is the biggest employer in West Africa accounting for $66 \%$ of total employment. While the majority of food economy jobs are in agriculture, off-farm employment in food-related manufacturing and service activities is increasing as the food economy adapts to rapid population growth, urbanisation and rising incomes. Given the importance of the food economy in generating employment, its current structure and projected changes have major implications for the design of jobs strategies. This paper quantifies and describes the structure of employment in the food economy across four broad segments of activities: agriculture, processing, marketing and food-away-from home. It also examines some of the emerging spatial implications, in particular rural-urban linkages and rural employment diversification, which are related to the transformations that are reshaping this sector. Finally, it looks at policy considerations for designing targeted employment strategies that leverage the links between agricultural productivity, off-farm employment and rural-urban areas and that ensure inclusiveness, particularly for youth and women.
\end{abstract}

Keywords: food system, employment, youth, women, value chains

JEL Classification: J21, J43, O11, Q13, Q18

\title{
NOTE
}

This work has been carried out within the framework of the programme of work and budget of the Sahel and West Africa Club Secretariat.

The German Federal Ministry for Economic Cooperation and Development (BMZ) has contributed additional funding to this work.

\section{THE SAHEL AND WEST AFRICA CLUB}

The Sahel and West Africa Club (SWAC) is an independent, international platform.

Its Secretariat is hosted at the Organisation for Economic Co-operation and Development (OECD).

\section{Mission}

SWAC's mission is to promote regional policies that will improve the economic and social well-being of people in the Sahel and West Africa.

\section{Objectives}

- Improve the regional governance of food and nutrition security.

- Improve the understanding of ongoing transformations in the region and their policy implications through regional, spatial and forward-looking analyses.

\section{Members}

Austria, Belgium, Canada, CILSS, the ECOWAS Commission, the European Union, France, Luxembourg, the Netherlands, Switzerland, the UEMOA Commission and the United States.

The World Bank, the Nepad Planning and Co-ordination Agency and the Network of Farmers' Organisations and Agricultural Producers of West Africa are observers.

SWAC has memorandums of understanding with the NEPAD Agency and the University of Florida (Sahel Research Group).

For more information: http://www.oecd.org/swac. 


\section{TABLE OF CONTENTS}

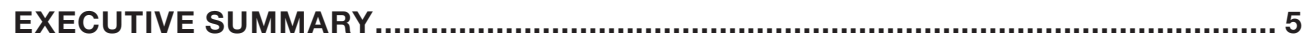

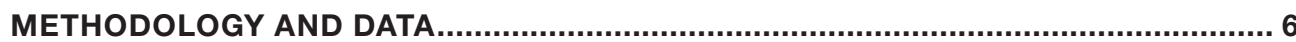

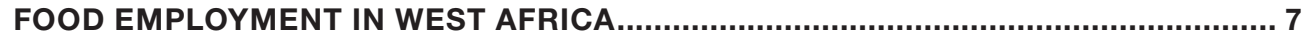

The food employment situation …....................................................................... 7

The importance of agriculture in food economy employment.............................. 8

Off-farm food economy employment................................................................ 10

The rural and urban food employment dimension …................................................................. 14

Youth and gender dimensions in food system employment ................................ 16

ECONOMIC AND SPATIAL DIMENSIONS OF FOOD EMPLOYMENT ....................... 20

Food value chains and off-farm food economy employment................................ 20

Spatial dimensions and rural-urban linkages .................................................... 22

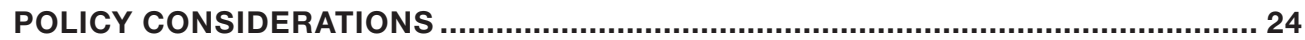

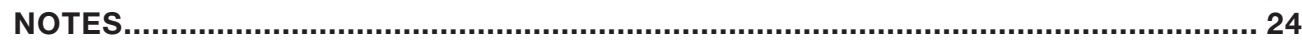

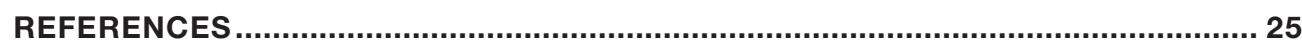

ANNEX 1: DATA SOURCES AND STANDARDISATION ......................................... 27

ANNEX 2: EMPLOYMENT MODELLING - TEN COUNTRIES .................................... 28 


\section{EXECUTIVE SUMMARY}

$\mathbf{T}$ he food economy is the biggest employer in West Africa. The various activities involved in producing food, from the farm to processing, packaging, transporting, storing, distributing and retailing, account for $66 \%$ of total employment, or 82 million jobs. While the majority of these jobs (78\%) are in agriculture, off-farm employment in food-related manufacturing and service activities is growing in number and share.

Urbanisation and rising incomes are driving major transformations in the food economy. Households increasingly rely on markets and look for foods that are more diverse and convenient to buy, prepare and consume. This transformation in local diets cuts across all countries and income groups and involves a move towards increased consumption of higher-value perishable and processed products (Staatz and Hollinger, 2016; Allen and Heinrigs, 2016; Reardon et. al., 2015). The changes in what people consume and how they access food are also driving demand for new and greater activities along food value chains, the majority of which are in the off-farm segments of the food economy.

As a result, labour demand in off-farm activities related to food processing, food marketing and other food services such as food-away-from-home, is on the rise. Off-farm activities account for $22 \%$ of total food economy employment and $31 \%$ of total non-farm employment. Food marketing activities (transport, logistics, retail, and wholesale) account for the largest share of off-farm food economy employment (68\%), followed by food processing (22\%). Given the size of the food economy these activities play an important role in overall employment. In Côte d'Ivoire, for example, food processing is the largest contributor to formal sector value added and the second largest contributor to formal employment (14\%) (Hebous and Tran, 2017). In Senegal, food processing is the largest manufacturing sub-sector and grew by 7.4\% per year between 2000 and 2010. Food-away-from-home activities which include street food, restaurants and other catering services, generate $10 \%$ of overall off-farm food economy employment, with much higher shares in some urban areas. This shift in labour demand will increase as the food system, including agriculture, continues to specialise and diversify, providing employment opportunities in local food economies.

But successful development of the untapped employment and production potential in the food economy requires an essential understanding of the food system, including local and spatial contexts. Well-rounded jobs strategies, in particular for youth and women, need to integrate a systems approach that captures the links between agricultural productivity, off-farm employment and rural and urban areas. Promoting non-agricultural employment will depend on supporting private enterprises, in particular SMEs, to drive growth and job creation. Policies aimed at supporting value chain development, integrated skills development and systems as well as improving the overall business climate are important elements in the jobs agenda.

In addition, off-farm activities and the food economy in general, play a particularly important role in women's employment. Sixty-eight percent of all employed women work in the food economy. Women dominate employment in off-farm segments including foodaway-from-home, food processing and food marketing. Yet women rarely have access to the resources needed to develop their activities in relation to their potential and ambitions. Policies and investments promoting off-farm food economy activities will have a particularly large impact on women.

The employment opportunities in food value chains, including in farming, require skill sets that are rapidly evolving. Anticipating and supporting these educational requirements are of major importance to the jobs agenda. Equipping youth, and in particular young women, with the necessary skills and education and reducing barriers to productive resources, will significantly promote employment potential and diversification.

This paper aims to contribute to the debate by quantifying and describing the current structure of employment in the West African food economy and by looking at some of the emerging spatial and territorial implications linked to the transformations that are reshaping this sector. 


\section{METHODOLOGY AND DATA}

D roducing and supplying food of the right quality and quantity for consumers depends on an increasing number of connected activities and actors. These food economy activities range from primary production, processing and transport to marketing and other food services such as restaurants and street food. Given the importance of the food economy in generating employment in West Africa, its current employment structure and projected changes have major implications for designing employment strategies. However, food economy activities are spread across different categories in national accounts (primary, secondary and tertiary sectors) making it difficult to compile data on employment in the food economy as a whole (Figure 1).

The main sources used to estimate employment in the food economy are micro-level data from the World Bank Living Standards Measurement Study with its Integrated Surveys on Agriculture (LSMS-ISA) and labour surveys. These sources provide detailed information on the labour allocation of the economically active population by activity ${ }^{1}$ and time use (hours of labour supplied per worker). Following Tschirley et al. (2017)², labour allocation is used to categorise jobs into four food economy segments ${ }^{3}$ :

1. Food agriculture, including agricultural self-employment and wage employment in activities within the primary sector dedicated to the production of agricultural products for human consumption;

2. Food processing, including all food and agricultural products for consumption and beverages;

3. Food marketing, including all transport, wholesaling and retailing activities related to food; and

4. Food-away-from-home, which includes restaurants, street food and other catering services.

The remaining employment is categorised as non-food economy employment.

However, LSMS data are available for only five countries in West Africa (Burkina Faso, Ghana, Mali, Niger and Nigeria) and recent labour surveys for Côte d'Ivoire (2012) and Senegal (2015). These seven countries account for $82 \%$ of West Africa's total population. No recent detailed employment data is available for the other ten countries. For these, estimations of food economy employment are based on macroeconomic modelling, building on broad sector employment data from the International Labour Organisation (ILO). ${ }^{4}$

While the LSMS and labour survey data provide robust results for the analytical purpose and level of aggregation used in this paper, a number of data issues need to be mentioned, in particular in view of the importance of the employment topic. The LSMS-ISA programme is a major source of information, particularly in relation to farm labour. However, the aggregation of off-farm activities in the food processing, food marketing and food-awayfrom-home segments prevents a detailed understanding of the employment structure in these activities. In addition, there are concerns about the coherence and reliability of the data collected. Time use data, crucial for estimating labour productivity and time-related underemployment, show important variations across countries. The same observation can be made for inactivity figures, which are particularly relevant for youth employment. Even more challenging are the discrepancies across different data sources for key variables such as urbanisation levels, a fundamental variable in the employment and diet transition. For instance, according to the LSMS data, the level of urbanisation in Mali for 2014 was 23\%, compared to $39 \%$ in the United Nations World Urbanisation Prospects (UN WUP) ${ }^{5}$; for Nigeria the difference is $37 \%$ (LSMS) and 50\% (UN). Since this population data is used to compute households' weights and to balance the sample in order to make it representative of the overall population, the impact on employment distribution within the food economy is significant. In Mali, the share of off-farm employment would increase by more than $40 \%$ and in Nigeria by $12 \%$ if the higher levels of urbanisation were used. 
The available data are not sufficient to adequately design and monitor employment policies and programmes for operational purposes. There is a strong need to better understand labour allocation decisions at the micro-level and how these decisions are linked throughout the food system. Given the strong influence of local and territorial characteristics, more spatially explicit data are also needed to understand the impact on labour markets.

\section{FOOD EMPLOYMENT IN WEST AFRICA}

\section{The food employment situation}

$\mathbf{T}$ he food economy accounts for $\mathbf{6 6} \%$ of total employment (Figure 1). Most of these jobs are in agriculture (78\%). Jobs outside agriculture but within the food economy food processing, food marketing and food-away-from-home - account for the remaining $22 \%$ of total food economy employment. However, given the large size of the food economy, off-farm food economy jobs are a major sector of employment. At the regional level, they account for 31\% of total non-agricultural employment. Food processing accounts for 30\% of total secondary sector employment, while food marketing and food-away-from-home represents $31 \%$ of total tertiary sector employment (Figure 1).

Figure 1

Employment structure in West Africa

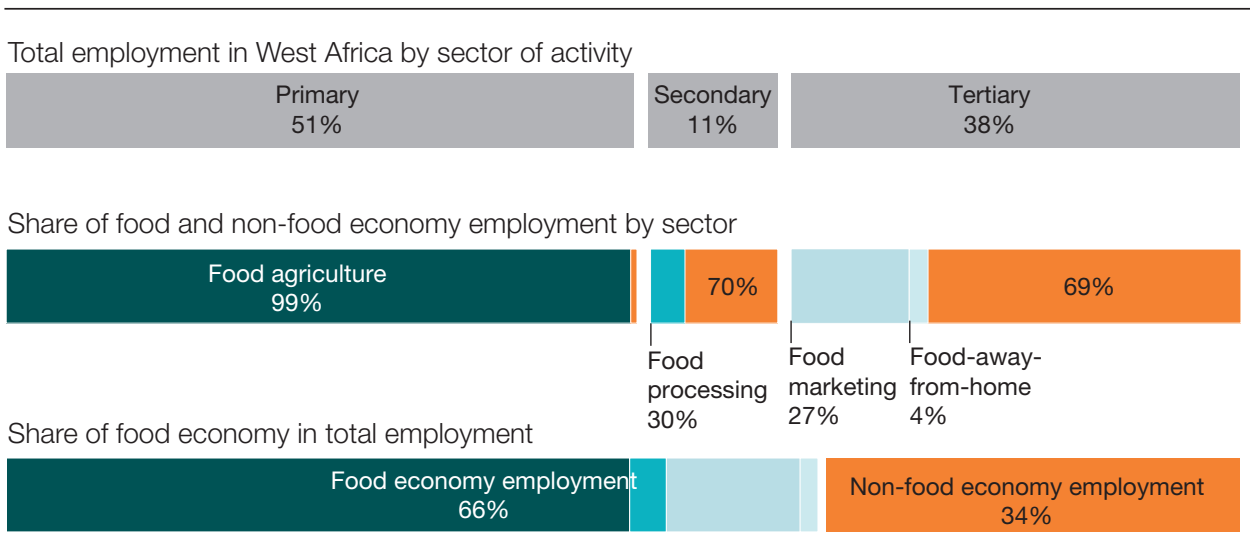

Share of food economy segments in total food economy employment

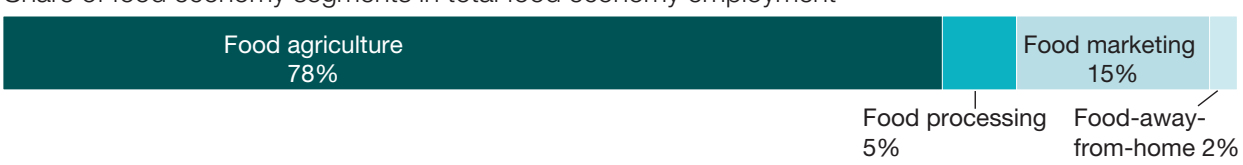

Source: Authors' calculations based on ANSD (2015), Enquête nationale sur l'emploi 2015 (database) ; World Bank (2017a), World Development Indicators (database) ; ILO (2017), Employment by sector, ILOSTAT (database) ; INS (2012), Enquête nationale sur la situation de l'emploi 2012, Côte d'Ivoire (database).

The share of food economy employment varies significantly across countries. In Chad, Niger, Mali and Burkina Faso it accounts for more than $80 \%$ of total employment, whereas in some coastal countries (Gambia, Senegal, Cabo Verde and Liberia) it accounts for less than 50\% (Figure 2). These differences in employment shares reflect differences in gross domestic product (GDP) per capita levels as well as employment share in agriculture; countries with lower levels of GDP per capita and higher shares of employment in agriculture tend to have higher shares of the workforce engaged in the food economy (Table 1).

The observed employment patterns reflect structural transformation processes in line with Engel's Law, stating that as income rises, food consumption represents a smaller share of household budgets and the share of the food economy in total GDP and employment, decreases. However, cross-country differences are also influenced by other country specific characteristics, such as food imports, agricultural exports and level of urbanisation. 
For instance, in some countries like Burkina Faso, Côte d'Ivoire, Ghana and Mali, agricultural employment is also influenced by the size of agricultural export sectors (e.g. cocoa, cotton and rubber). In the case of Mali and Burkina Faso, cotton production is contributing strongly to agricultural employment, but is not linked to food consumption patterns. ${ }^{6}$ In Côte d'Ivoire and Ghana, the cocoa sector contributes significantly to agricultural and food agriculture employment, but is driven by global demand and not domestic transformations in income and consumption. Also, characteristics in terms of geography (Cabo Verde, Gambia), level and size of urban population, and importance of food imports, influence broader patterns (Table 1).

\section{Figure 2}

Share and number of people employed in the food economy

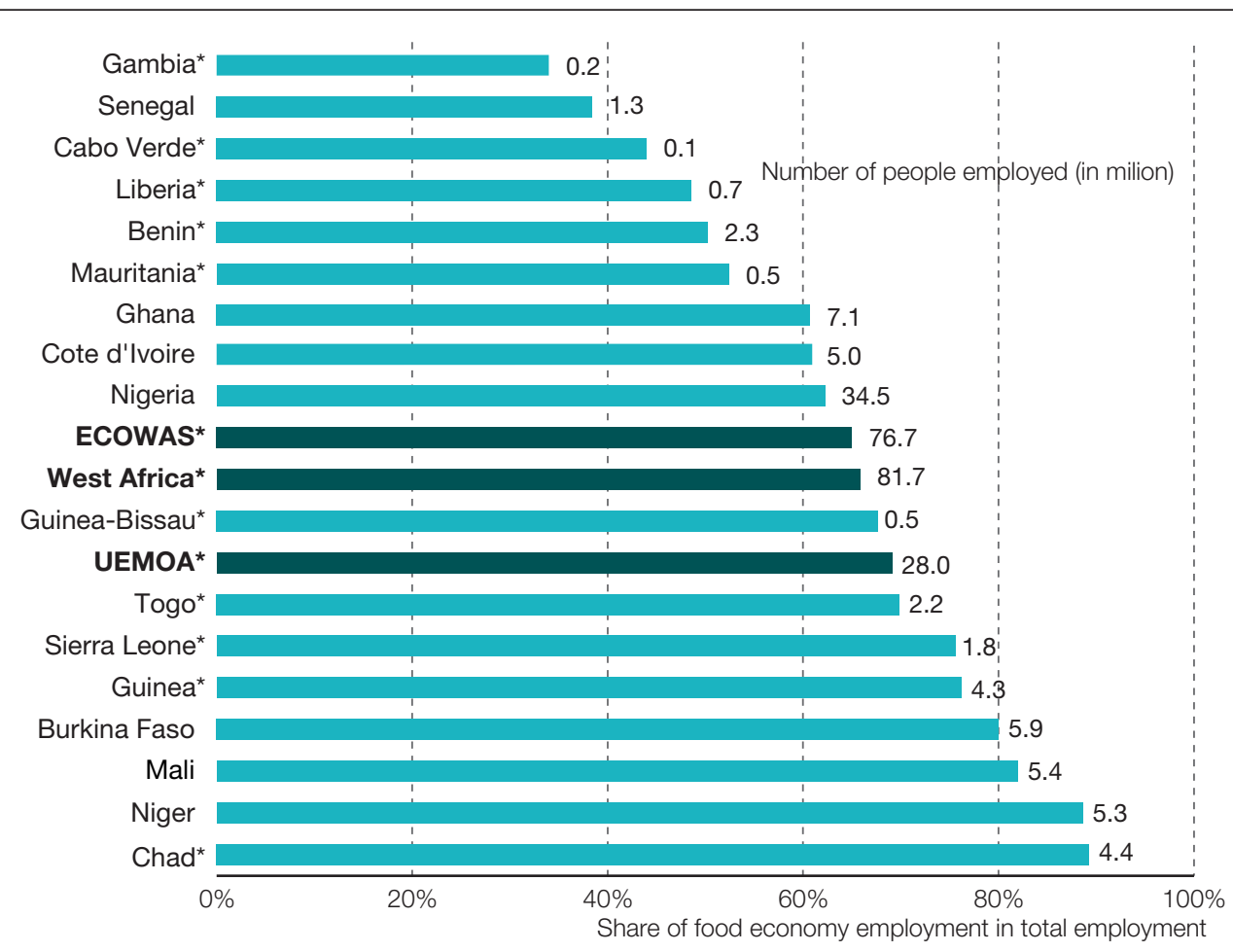

Note: *Modelled data. Economic Community of West African States (ECOWAS), West African Economic and Monetary Union (UEMOA)

Source: Authors' calculations based on ANSD (2015), World Bank (2017a), ILO (2017), INS (2012).

However, employment patterns in the food economy are primarily driven by local food demand (Tschirley et. al., 2016). At the regional level, the vast majority of food consumption comes from local food production, with food imports representing only 8\% of total food expenditure (Allen and Heinrigs, 2016). ${ }^{7}$ Food imports and exports also generate employment in the food system. Imports of unprocessed or lightly processed foods such as cereals generate employment in processing and marketing segments, while food exports generate agricultural employment and, to a lesser extent, food processing and food marketing (transport, storage and logistics) employment.

\section{The importance of agriculture in food economy employment}

Food agriculture is the largest food economy segment in terms of employment, accounting for $78 \%$ of all food economy jobs at the regional level. Although there are significant differences across countries, at least two-thirds of total food economy employment in all countries is in agriculture (Figure 3). The high share of employment in food agriculture is closely related to existing farming systems and production techniques. Agriculture in the region can be characterised by a high share of family farms and small-holders, labour intensive production techniques and small farm sizes. However, such averages hide the strong heterogeneity in existing farming systems. In all countries, large scale mechanised farms and high-productivity medium-sized family farms co-exist with more traditional farms. 
Table 1

Food economy employment and the rest of the economy

\begin{tabular}{|c|c|c|c|c|c|}
\hline & $\begin{array}{l}\text { GDP per capita } \\
\text { (USD PPP) }\end{array}$ & $\begin{array}{l}\text { Agricultural } \\
\text { employment } \\
\text { (\% of total) }\end{array}$ & $\begin{array}{l}\text { Food economy } \\
\text { employment } \\
\text { (\% of total) }\end{array}$ & $\begin{array}{l}\text { Food imports } \\
\text { (\% of GDP) }\end{array}$ & $\begin{array}{l}\text { Urbanisation } \\
\text { level }^{\star \star}\end{array}$ \\
\hline Cabo Verde & 6302 & $28 \%$ & $45 \%{ }^{*}$ & $12 \%$ & $50 \%$ \\
\hline Nigeria & 5670 & $43 \%$ & $62 \%$ & $2 \%$ & $37 \%$ \\
\hline Ghana & 3940 & $44 \%$ & $61 \%$ & $6 \%$ & $50 \%$ \\
\hline Mauritania & 3835 & $41 \%$ & $53 \%$ & $5 \%$ & $43 \%$ \\
\hline Côté d'lyoire & 2762 & $52 \%$ & $61 \%$ & $7 \%$ & $42 \%$ \\
\hline Senegal & 2445 & $32 \%$ & $39 \%$ & $9 \%$ & $51 \%$ \\
\hline Chad - & 2180 & $77 \%$ & $89 \%^{*}$ & - & $28 \%$ \\
\hline Benin & 2116 & $44 \%$ & $51 \%{ }^{*}$ & $12 \%$ & $48 \%$ \\
\hline Mali - - & 1965 & $75 \%$ & $82 \%$ & $4 \%$ & $23 \%$ \\
\hline Gambia & 1691 & $30 \%$ & $34 \%^{*}$ & $18 \%$ & $37 \%$ \\
\hline Burkina Faso & 1618 & $72 \%$ & $80 \%$ & $4 \%$ & $22 \%$ \\
\hline Guinea-Bissau & 1516 & $61 \%$ & $68 \%{ }^{*}$ & - & $56 \%$ \\
\hline Togo & 1438 & $63 \%$ & $70 \%^{*}$ & $9 \%$ & $50 \%$ \\
\hline Sierra Leone & 1401 & $68 \%$ & $76 \%$ * & $7 \%$ & $37 \%$ \\
\hline Guinea & 1261 & $70 \%$ & $77 \% \%^{*}$ & $8 \%$ & $34 \%$ \\
\hline Niger & 948 & $81 \%$ & $89 \%$ & $7 \%$ & $16 \%$ \\
\hline Liberia & 836 & $45 \%$ & $49 \%{ }^{*}$ & - & $42 \%$ \\
\hline
\end{tabular}

Notes: Purchasing power parity United States dollars (USD PPP) *Modelled data. ${ }^{\star \star}$ LSMS or Labour survey data for Burkina Faso, Cote d'Ivoire, Ghana, Mali, Niger, Nigeria and Senegal. Africapolis for the other 10 countries. Cell colouring based on conditional formatting by column, darker colours reflect higher cell values.

Sources: Authors' calculations based on ANSD (2015), World Bank (2017a), INS (2012), OECD/SWAC (forthcoming).

Figure 3

Structure of food economy employment by segment (in number of jobs or full-time equivalents)

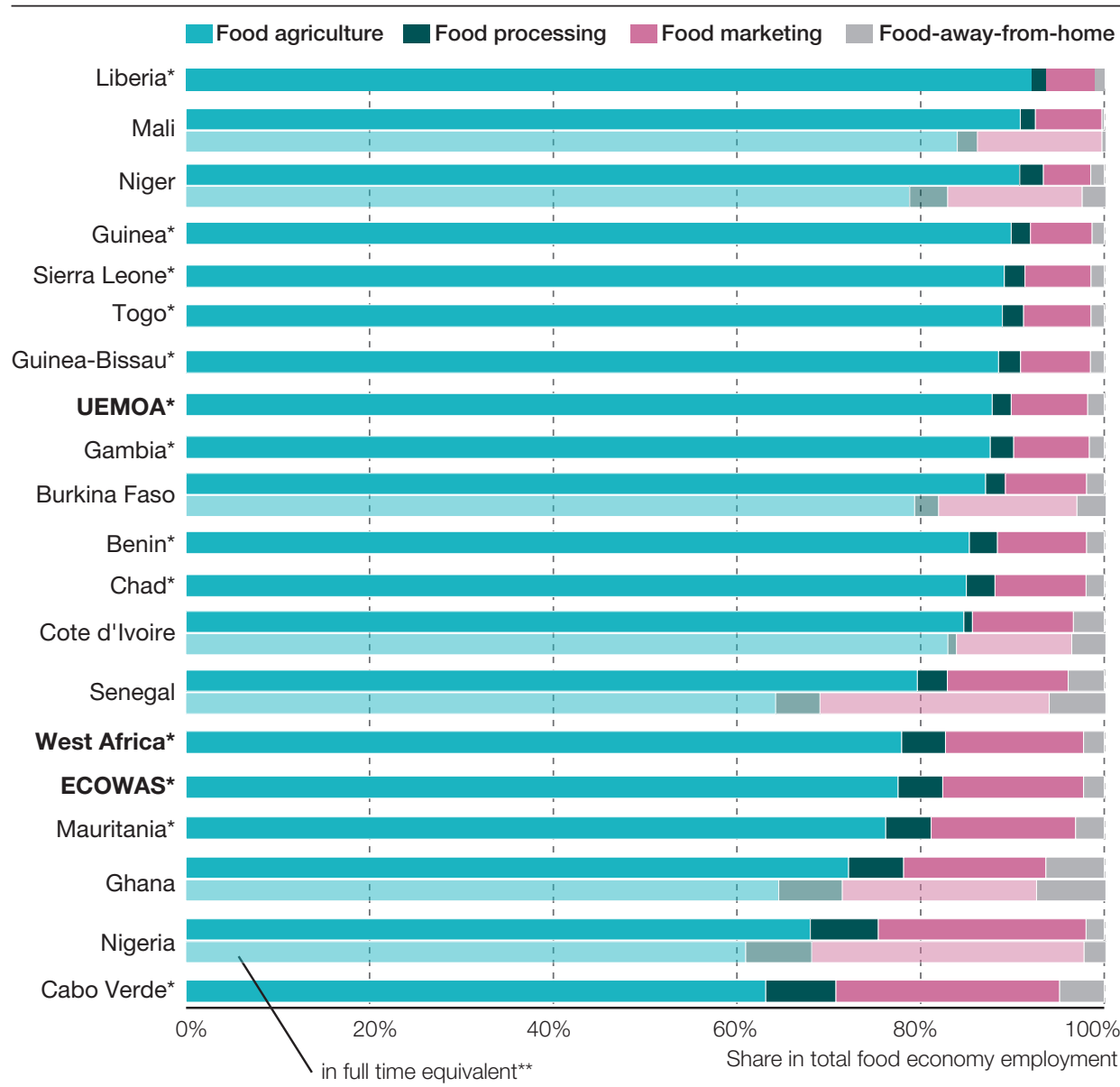

Note: *Modelled data

Source: Authors' calculations based on ANSD (2015), World Bank (2017a), ILO (2017), INS (2012). 
The interactions between agricultural production systems, labour demand and broader structural transformations are also captured by the relationship between GDP per capita and the share of workers engaged in agriculture. Cabo Verde, Nigeria and Ghana have the highest GDP per capita as well as the lowest share of food agriculture jobs (Figure 3). Niger, one of the poorest countries in the region has one of the highest shares of farming jobs. The relationship is less clear between these extremes with other factors impacting labour shares.

Agricultural productivity differences can have a significant impact on estimated employment shares. There is a growing body of evidence showing large agricultural productivity differences across countries and also within countries. One method of capturing productivity differences and their employment impact is to look at actual hours worked, or full-time equivalents (FTE), ${ }^{8}$ instead of declared activity (McCullough, 2017). In the seven countries for which data are available, those in agriculture work significantly fewer hours than those in downstream segments of the food economy. On average, farmers work 26 hours a week (first declared activity only), compared to 39 hours on average in downstream segments. This time-related, or visible, ${ }^{9}$ underemployment in agriculture is linked to its seasonal nature and/or contexts where surplus production (and hence additional labour effort) does not pay because markets are absent or too costly to reach (Christiaensen and Premand, 2017).

For example, estimating employment shares for Niger and Burkina Faso using FTEs instead of declared activity, shows that the share of food agriculture in total food economy employment drops significantly, from $91 \%$ to $74 \%$ and from $87 \%$ to $75 \%$, respectively (Figure 3). While time-related underemployment affects agricultural activities in particular, the share of off-farm food economy employment in these countries is doubled. In Côte d'Ivoire, however, overall employment shares remain relatively stable whether in FTE or declared activity, indicating significantly lower levels of underemployment in agriculture. Christiaensen and Lawin (2017) confirm: "this lower underemployment [in Côte d'Ivoire] is consistent with the greater importance of cash crops and the greater use of hired labour, the country's further evolvement in the structural transformation, and its high degree of urbanisation." Underemployment and seasonal labour constraints in agriculture can also be reduced through investments in technology, irrigation, mechanisation or mixed farming systems (crops and livestock) as well as through investments into improving market access. Data for Senegal confirms the importance of production systems and market orientation on agricultural labour productivity (see Box 1).

For the seven countries for which data are available, estimated employment shares using FTEs, shows a decrease of food agriculture in total food economy employment by $10 \%$ (7 percentage points), from $75 \%$ to $68 \%$. Consequently, the share of off-farm food economy employment in total employment increases by a staggering 30\% (from 25\% to $32 \%$ ). The higher share of off-farm activities in the employment structure using FTEs appears better aligned with estimated labour productivity differences across sectors and the distribution of value added between food economy segments, with off-farm activities estimated to account for 40\% of the total food economy's value added in 2010 (Allen and Heinrigs, 2016).

\section{Off-farm food economy employment}

The three off-farm food economy segments - food marketing, food processing and food away from home - account for $22 \%$ of total food economy employment at the regional level. Although the distribution of employment in the off-farm segments varies by country, there is a clear pattern which shows that food marketing is the largest off-farm segment. Employment patterns in food processing and food-away-from-home segments across countries are less clear. Food marketing contributes 15\% to total food economy employment, followed by food manufacturing (5\%) and food away from home (2\%) (Table 2). Together, these segments account for 31\% of total non-farm employment in the region.

The development of the off-farm segments of the food economy is closely linked to changes in household dietary patterns. These changes, related to Bennett's Law, have recently 
Share of off-farm food employment in total food economy employment

\begin{tabular}{|c|c|c|c|c|}
\hline & $\begin{array}{l}\text { Total off-farm food } \\
\text { economy employment } \\
(1+2+3)\end{array}$ & $\begin{array}{l}\text { Food } \\
\text { processing } \\
\text { (1) }\end{array}$ & $\begin{array}{l}\text { Food } \\
\text { marketing } \\
\text { (2) }\end{array}$ & $\begin{array}{l}\text { Food-away- } \\
\text { from-home } \\
\text { (3) }\end{array}$ \\
\hline Cabo Verde* & $37 \%$ & $8 \%$ & $25 \%$ & $5 \%$ \\
\hline Nigeria & $32 \%$ & $7 \%$ & $23 \%$ & $2 \%$ \\
\hline Ghana & $28 \%$ & $6 \%$ & $16 \%$ & $6 \%$ \\
\hline Mauritania* & $24 \%$ & $5 \%$ & $16 \%$ & $3 \%$ \\
\hline West Africa* & $22 \%$ & $5 \%$ & $15 \%$ & $2 \%$ \\
\hline Cote d'Ivoire & $20 \%$ & $1 \%$ & $16 \%$ & $3 \%$ \\
\hline Senegal & $18 \%$ & $3 \%$ & $11 \%$ & $4 \%$ \\
\hline Chad $^{*}$ & $15 \%$ & $3 \%$ & $10 \%$ & $2 \%$ \\
\hline Benin* & $15 \%$ & $3 \%$ & $10 \%$ & $2 \%$ \\
\hline Burkina Faso & $13 \%$ & $2 \%$ & $9 \%$ & $2 \%$ \\
\hline Gambia* & $13 \%$ & $3 \%$ & $8 \%$ & $2 \%$ \\
\hline Guinea-Bissau* & $12 \%$ & $2 \%$ & $8 \%$ & $2 \%$ \\
\hline Togo* & $11 \%$ & $2 \%$ & $7 \%$ & $2 \%$ \\
\hline Sierra Leone ${ }^{\star}$ & $11 \%$ & $2 \%$ & $7 \%$ & $1 \%$ \\
\hline Guinea* & $10 \%$ & $2 \%$ & $7 \%$ & $1 \%$ \\
\hline Niger & $9 \%$ & $3 \%$ & $5 \%$ & $1 \%$ \\
\hline Mali & $9 \%$ & $2 \%$ & $7 \%$ & $0 \%$ \\
\hline Liberia* & $8 \%$ & $2 \%$ & $5 \%$ & $1 \%$ \\
\hline
\end{tabular}

Notes: *Modelled data. Cell colouring based on conditional formatting by column. Darker colours reflect higher cell values.

Sources: Authors' calculations based on ANSD (2015), World Bank (2017a), ILO (2017), INS (2012).

been documented for West Africa (Allen and Heinrigs, 2016; Staatz and Hollinger, 2016) and show that, with rising income and urbanisation, consumption of fresh and perishable products, such as fruits and vegetables, dairy, meats, and processed foods, increases rapidly. Perishable and processed foods demand more value added after the farm in terms of cold chains, processing and packaging. The employment effect of these food demand transformations is that work moves increasingly into the off-farm segments of the food system. In addition, the growth in food marketing activities is closely linked to the development of food markets.

\section{Food processing}

The food processing sector is the largest manufacturing sub-sector in terms of employment in the region. Although it accounts for just $5 \%$ of food economy employment, it represents $30 \%$ of total secondary sector employment. In Niger and Nigeria, food processing accounts for close to $50 \%$ of all manufacturing activities (Figure 4). Many of these jobs are in artisanal and small- and medium-sized enterprises in the informal economy. Yet a recent World Bank study, looking at formal sector employment in Côte d'Ivoire shows that “...food manufacturing (ISIC 15) stands out as the most important contributor to value added and the second biggest contributor to employment," adding further "while the share of firms in the agribusiness sector was only 4\% in 2012 it generated 18\% of jobs" (Hebous and Tran, 2017).

From a jobs perspective the food processing sector has three important features. First, agro-industries (e.g. millers, beer breweries, processors) are more likely than other industry sectors to locate outside primary cities including in small towns and more rural areas (Henderson and McNamara, 2000; Christiaensen and Lawin, 2017). Second, it creates strong forward and backward linkages with other food and non-food system activities. The food processing sector is a growing outlet for agricultural products, which generally translates into more stable demand. Both features imply potentially large employment effects in local economies. Furthermore, employment in the processing sector is dominated by women and tends to be unskilled and labour intensive, providing more inclusive opportunities. 
Figure 4

Share of food processing in total manufacturing employment (2012-15)

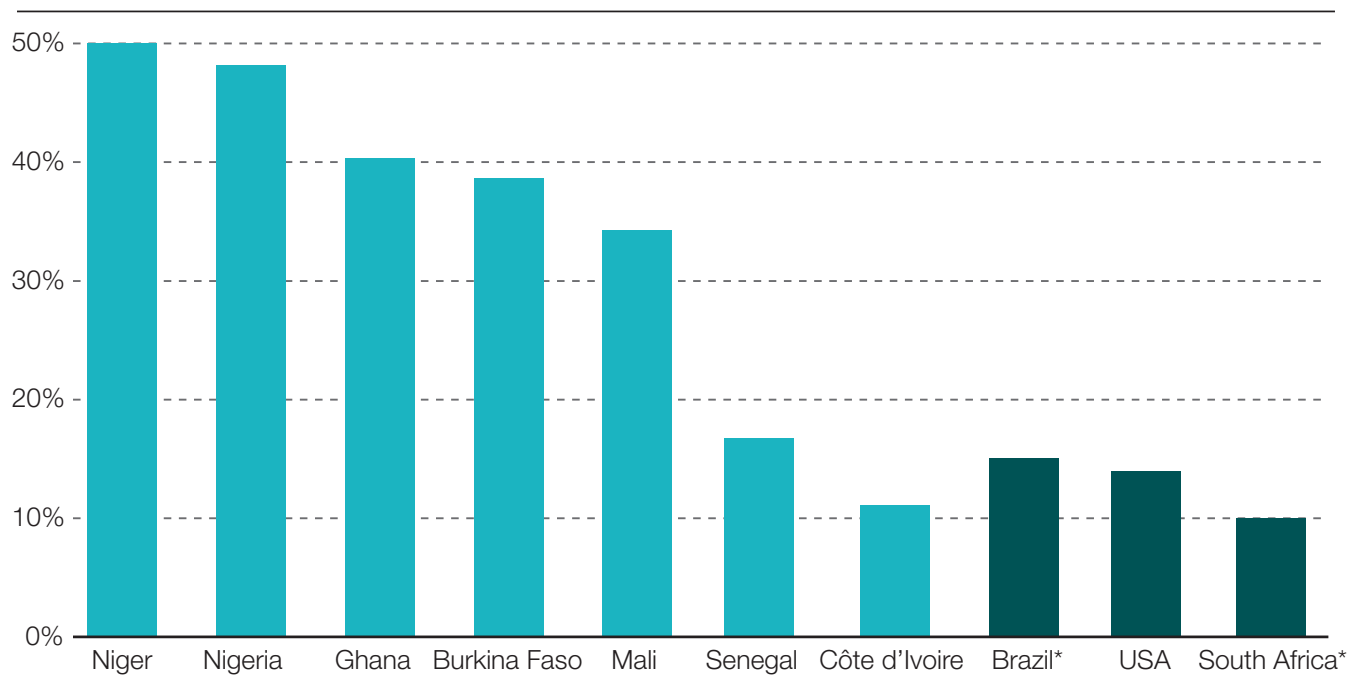

Note: *2008

Source: Authors' calculations based on ANSD (2015); World Bank (2017a); ILO (2012a), Sectoral country profil - Brazil; ILO (2012b), Sectoral country profil - South Africa; INS (2012); Nesheim et al. 2015.

Third, demand for food processing activities is projected to continue to grow over the medium-term. In Nigeria, based on food demand projections, employment in food processing is expected to grow 13\% over the next five years (Tshirley et. al., 2016). However, the growth of large-scale industrial processors is impacted by an unreliable supply of local raw materials of consistent quality, resulting in reliance on imported commodity inputs. Hence, from an employment perspective, growth in this sector will crucially depend on the capacity of local processors and agri-businesses to source from domestic production (Staatz and Hollinger, 2016).

\section{Food marketing}

Food marketing is the largest off-farm segment, accounting for more than $70 \%$ of all non-agricultural food economy jobs. Food marketing jobs - transport, storage, wholesale, retail - represent $27 \%$ of all service sector employment. The development of these activities is closely linked to urbanisation and the reliance on markets for gaining access to food. The role of markets in accessing food has grown significantly across the region due to urbanisation, with increasing shares of food being purchased, as opposed to produced, within the household. In addition, rural households also rely increasingly on markets to access foods. In Burkina Faso and Nigeria, rural households spend more than $60 \%$ of their food budget on markets, of which $36 \%$ is spent on processed foods. ${ }^{10}$ Also, changes in food demand and reductions in transport costs increase demand for foods produced further away (Tacoli and Agergaard, 2017).

More urbanised countries such as Ghana, Senegal, Côte d'Ivoire or Nigeria have the highest shares of total food employment in marketing activities, while Mali and Niger which are the least urbanised countries in the region, rank at the bottom (Table 2). Food marketing activities will continue to grow and provide the largest number of off-farm food jobs in the years to come.

\section{Food-away-from-home}

Food-away-from-home accounts for $2 \%$ of all food jobs and $10 \%$ of off-farm food jobs. The employment share varies substantially across countries. In Ghana and Senegal, it accounts for $6 \%$ and $4 \%$ of food economy jobs respectively, compared to $1 \%$ and less in Niger and Mali (Table 2). These figures mirror variations in expenditure shares on food-away-from-home services. In the region's main cities, food-away-from-home represents a substantial but varying share of household food expenditure, accounting 
for more than 30\% in Abidjan, Cotonou and Lomé to less than 10\% in Bamako, Conakry and Freetown (Bricas et al., 2016). These differences are explained by cultural factors, but also by differences in city size and configuration, transport network and working hours.

Food-away-from-home is closely associated with incomes and is projected to grow faster than other food segments (Staatz and Hollinger, 2016). In addition, the sector is highly important for women's employment (see following section) and generates high value added, also on imported products. It also creates strong linkages with other food sources providing regular demand for other food economy activities (Tschirley et. al., 2016).

\section{Figure 5}

Spatial distribution of food economy employment by segment and by location

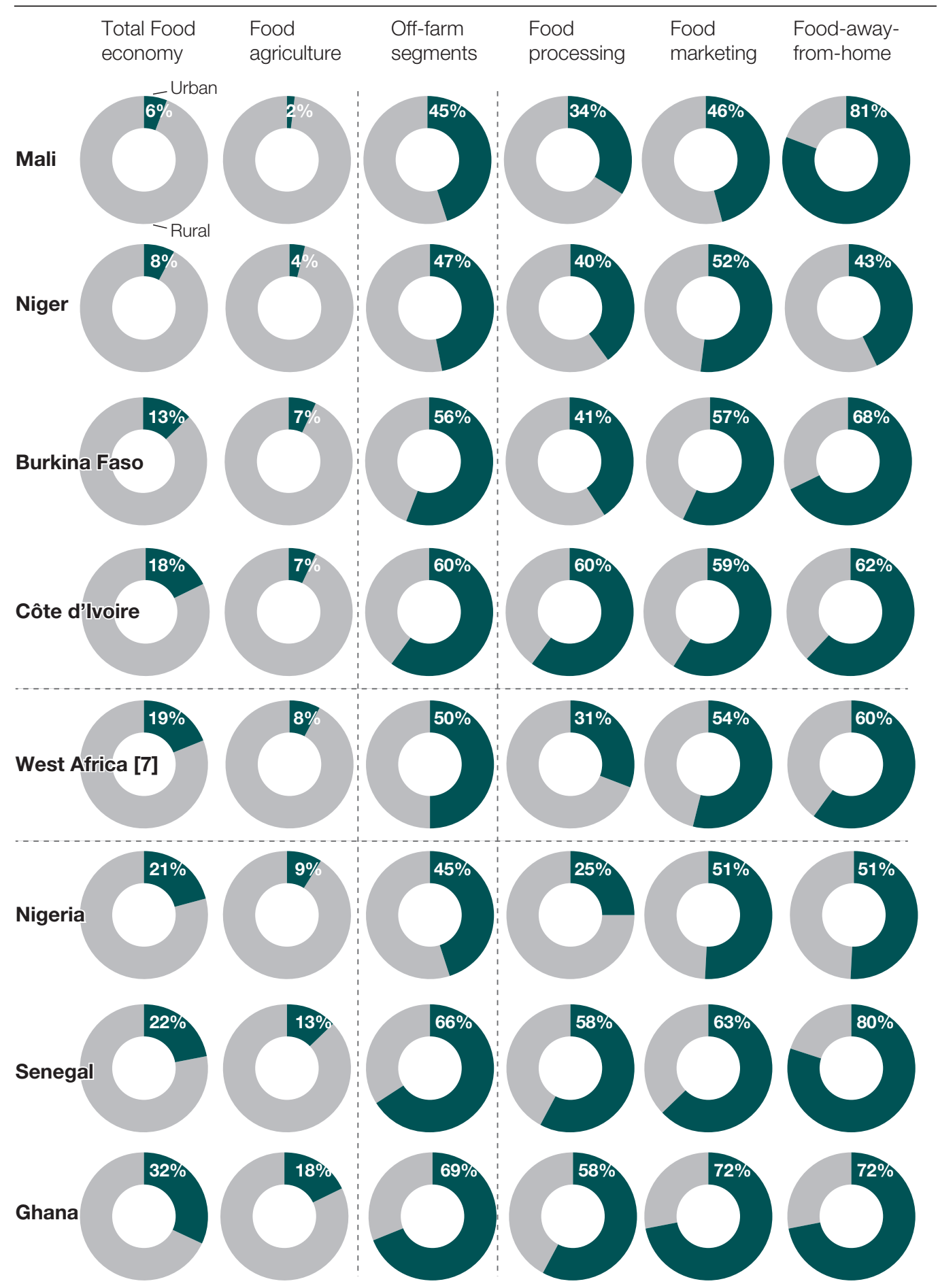

Source: Authors' calculations based on ANSD (2015), World Bank (2017a), INS (2012). 


\section{The rural and urban food employment dimension ${ }^{11}$}

Clear spatial patterns naturally appear in food economy activities. Agricultural activities are overwhelmingly rural while marketing and food-away-from-home activities, which are dependent on the size of and proximity to final consumption, are mostly urban. Food processing industries, however, show less pronounced urban-rural patterns and tend to be located in proximity to final demand or to rural areas where raw material production takes place. Overall, countries with a higher level of urbanisation (Ghana, Senegal and Côte d'Ivoire) also have larger shares of off-farm activities in urban areas (Figure 5).

\section{Rural food economy employment}

Overall, food economy employment accounts for 81\% of total rural employment (Figure 7). The high share of rural food economy employment is explained by the overall dominance of agricultural activities which account for $85 \%$ of rural food economy employment.

Looking at rural off-farm food economy employment shows two results. First, off-farm food economy segments can provide interesting employment diversification opportunities and second, there are large differences across countries and within countries (Map 1).

Overall, food marketing accounts for $10 \%$ of all rural food economy employment followed by food manufacturing (4\%) and food-away-from-home (1\%) (Figure 6). Countries with a more diversified food economy employment structure overall (higher share of off-farm activities), tend to also have more diversified rural employment, with higher shares of employment in all three off-farm segments (food processing, marketing and food-away-from-home). In Nigeria, food processing and marketing represent $7 \%$ and $14 \%$ respectively of total rural food economy employment, while they account for $2 \%$ and $3 \%$ in Niger (Figure 6). However, in Côte d'Ivoire, rural employment in food processing is particularly low compared to the size of its off-farm food sector. Employment diversification in rural areas reflects the broader transformations observed in the food economy. Labour demand in agriculture increases as dairy, meat, fish, fruits and vegetables are more labour intensive and off-set labour demand reductions in staple crop production. Labour demand in the off-farm segments of the food economy increases due to the higher shares of associated activities in storage, transport, processing, packaging, wholesale and retail (Christiaensen and Premand, 2017). In addition, the growth in rural off-farm activities is also linked to the development of more diverse rural food markets, including demand for food-away-fromhome (driving employment demand in off-farm segments).

Figure 6

Rural food economy employment diversification

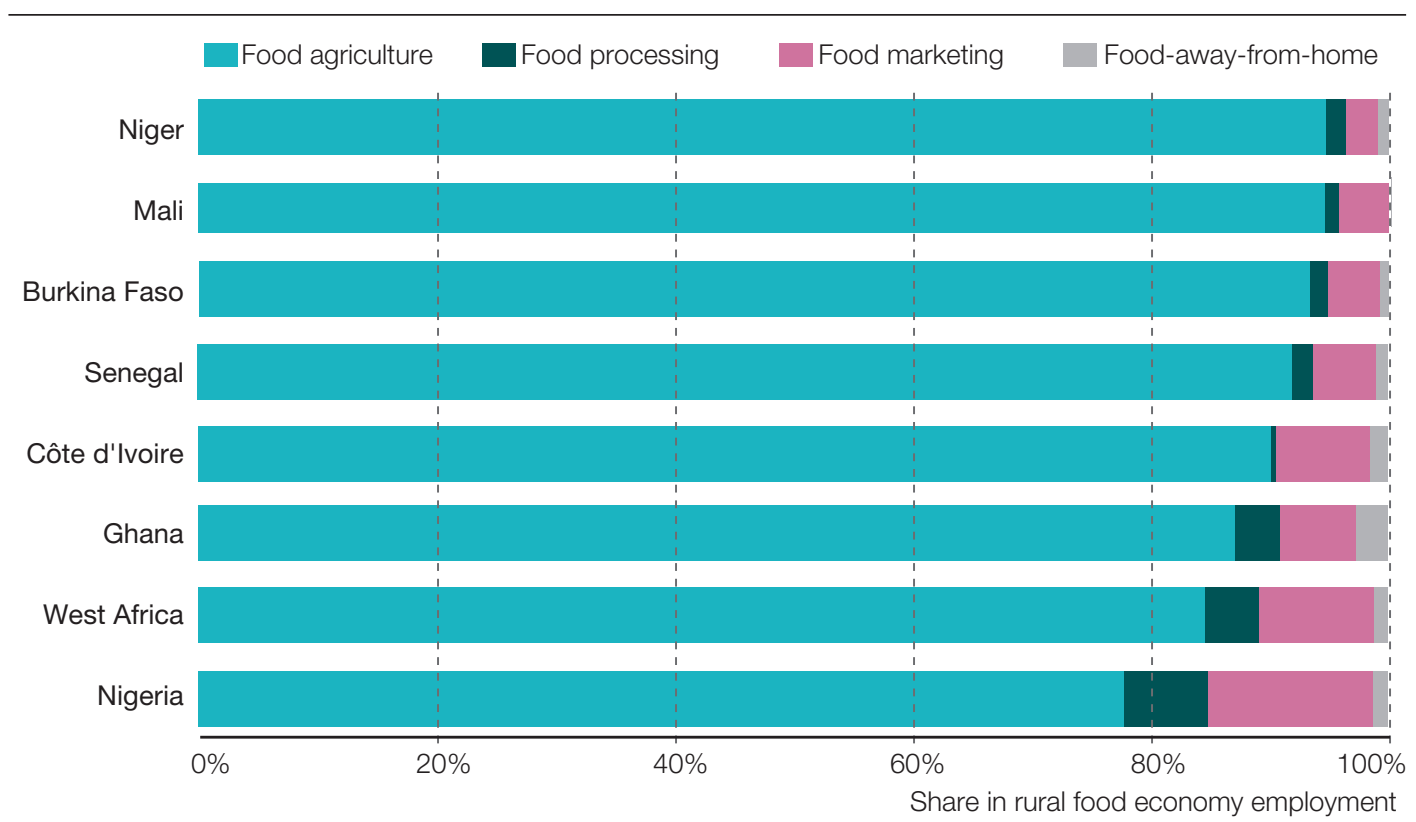

Source: Authors' calculations based on ANSD (2015), World Bank (2017a), INS (2012). 
Food processing and marketing are critical to the development of food value chains. The relatively low employment shares in rural areas mask the important role these activities play in agricultural growth, income generation and rural transformation. These activities are the entry points to market connections, linking food production to food consumption. Grading, storing and wholesaling allow processors to access raw materials; packaging is necessary for product conservation and transport and logistics and wholesaling are crucial for reaching end consumers. Proximity to these interconnected off-farm activities is also driving agricultural production and intensification (Proctor and Berdegué, 2016; Jayne et. al., 2014).

\section{Urban food economy employment}

Overall, food economy jobs represent 35\% of total urban employment (Figure 7). Food marketing and food-away-from-home account for $57 \%$ of all urban food economy jobs. These jobs are closely linked to the size of food markets and vary strongly across countries. In Ghana, Senegal and Côte d'Ivoire, 66\% of employment in food marketing and foodaway-from-home is in urban areas, compared to 52\% in Mali, Niger and Burkina Faso.

The majority of these jobs are vendors in small shops, street markets, hawkers or food stalls and street food. These mostly informal activities are central to the urban food marketing system, providing the bulk of the urban food supply. In particular, poor urban households are dependent on these distribution networks, often purchasing small quantities on a daily basis and relying on street food vendors because of the costs of preparing one's own food and the lack of facilities to prepare and store food at home (Proctor and Berdegué, 2016).

Figure 7

Share of food economy employment in total employment by location

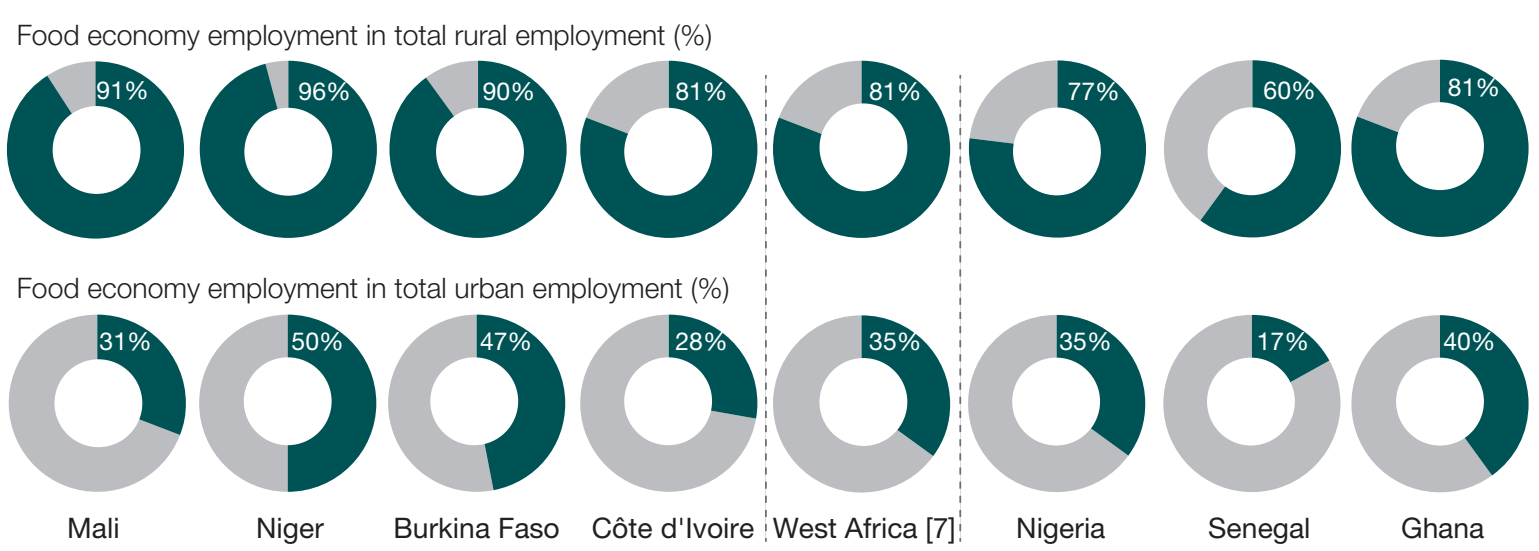

Source: Authors' calculations based on ANSD (2015), World Bank (2017a), INS (2012).

Food agriculture accounts for 34\% of all jobs in the urban food economy (8\% of total food agriculture employment). In Burkina Faso and Senegal, the share of agriculture reaches $46 \%$. In Nigeria and Niger (the only countries for which detailed geo-localised information is available), the majority of these urban producers are located in small- and medium-sized cities. Most of the agricultural activities in urban areas are on micro plots of high-value perishable food products such as vegetables, where producers are able to overcome land use constraints and benefit from their proximity to markets. In certain cities, geographical factors account for a high share of food agricultural activities as is the case with fishing in many coastal towns. For instance, in Ablekuma South, a dense district of Accra (Ghana), 18\% of households are engaged in fishing, which is the second most common activity behind kenkey (a maize-based staple dish) and fish processing (23\% of households) (Ministry of Food and Agriculture of Ghana, 2016). However, the share of agricultural activities in urban areas is likely to be inflated by households living in urban areas but engaging in farming activities located outside urban boundaries. 


\section{Youth and gender dimensions in food system employment}

\section{Youth employment diversification}

Youth are of particular importance to the jobs agenda given their high share in the total population. In West Africa, 19\% of the population is between 15-24 years, representing $36 \%$ of the total working age population (15-65 years). Young adults, between 25-34 years, add another $26 \%$ to the total working age population.

Overall, youth have the lowest labour force participation rate, with large differences across countries, rural and urban areas, and gender (Table 3). Youth labour force participation rates are significantly lower in coastal countries ranging from 33\% to 57\% compared with non-coastal countries - Niger, Mali and Burkina Faso - where youth participation rates range from $64 \%$ to $82 \%$. These high participation rates are strongly influenced by the high level of youth activity in rural areas combined with a high share of rural youth within total youth populations. In all countries, youth labour force participation rates are higher in rural areas than in urban areas and among young men. The only exception is Côte d'Ivoire where the female youth labour force participation in urban areas exceeds that of male participation.

$\underline{\text { Table } 3}$

Youth labour force participation rate by residence and gender, and for adult working age population

\begin{tabular}{|c|c|c|c|c|c|c|}
\hline & \multirow{3}{*}{$\begin{array}{l}\text { Total youth } \\
\text { population } \\
(15-24)\end{array}$} & \multicolumn{4}{|c|}{ Youth (15-24) } & \multirow{3}{*}{$\begin{array}{c}\text { Total adult working } \\
\text { age population } \\
(25-65)\end{array}$} \\
\hline & & \multicolumn{2}{|c|}{ Urban } & \multicolumn{2}{|c|}{ Rural } & \\
\hline & & Male & Female & Male & Female & \\
\hline Burkina Faso & $82 \%$ & $55 \%$ & $52 \%$ & $96 \%$ & $92 \%$ & $93 \%$ \\
\hline Ghana & $71 \%$ & $32 \%$ & $26 \%$ & $89 \%$ & $83 \%$ & $83 \%$ \\
\hline Mali & $64 \%$ & $46 \%$ & $18 \%$ & $86 \%$ & $64 \%$ & $81 \%$ \\
\hline West Africa [7] & $57 \%$ & $44 \%$ & $42 \%$ & $74 \%$ & $71 \%$ & $92 \%$ \\
\hline Nigeria & $53 \%$ & $35 \%$ & $42 \%$ & $72 \%$ & $64 \%$ & $82 \%$ \\
\hline Côte d'Ivoire & $46 \%$ & $32 \%$ & $31 \%$ & $60 \%$ & $49 \%$ & $83 \%$ \\
\hline Niger & $36 \%$ & $27 \%$ & $26 \%$ & $48 \%$ & $35 \%$ & $82 \%$ \\
\hline Senegal & $33 \%$ & $34 \%$ & $20 \%$ & $52 \%$ & $27 \%$ & $58 \%$ \\
\hline
\end{tabular}

Note: Cell colouring based on conditional formatting, darker colours reflect higher cell values. First and last column formatting conditioned on column values; values in column 2, 3, 4, 5 conditional formatting on row values.

Sources: Authors' calculations based on ANSD (2015), World Bank (2017a), INS (2012)

The majority of economically inactive youth are enrolled in education (73\%). Again, area of residence (rural/urban) and gender play an important role. More urban youth (77\%) and young men (78\%) are enrolled in education than young women (55\%). Thirty percent of economically inactive young women stay at home and this percentage tends to increase in rural areas (42\%). Also, economic inactivity and unemployment tend to be higher among wealthier groups, with people at the bottom of the wealth distribution unable to afford inactivity or unemployment (Christiaensen and Premand, 2017). Yet economic inactivity levels drop quickly with age; $61 \%$ of 15-19 year olds are inactive while only $30 \%$ of $25-29$ year olds are inactive.

Overall, 73\% of employed youth (15-24) live in rural areas, of which 60\% are men. In Mali, Niger and Burkina Faso, the share of employed youth living in rural areas is significantly higher at $90 \%, 87 \%$ and $80 \%$, respectively. This is also clearly reflected in the high share of agricultural employment (63\%) in total youth employment (Figure 8).

Youth entering the labour force do so predominantly in non-agricultural sectors. The 30 to 34 age cohort is the least engaged in agriculture (Figure 8). This pattern is particularly strong in countries with higher shares of inactive youth due to higher enrolment rates in education (Côte d'Ivoire, Ghana, Nigeria and Senegal). In Nigeria, for instance, 71\% of the active 15 to 19 age cohort works in agriculture as opposed to 31\% for the 30-34 age cohort. Though the pattern is much less pronounced in Burkina Faso, Mali and Niger, it is still significant. In Burkina Faso agriculture accounts for $80 \%$ of total employment of 
15-19 year olds, but drops to 64\% for the 30-34 age cohort. Agriculture's low entry barriers, in particular on family farms, and the absence of alternative employment opportunities for this age group should explain the high levels of agricultural participation for active 15 to 19 year olds (McCullough, 2017).

Figure 8

Share of agricultural employment by age group

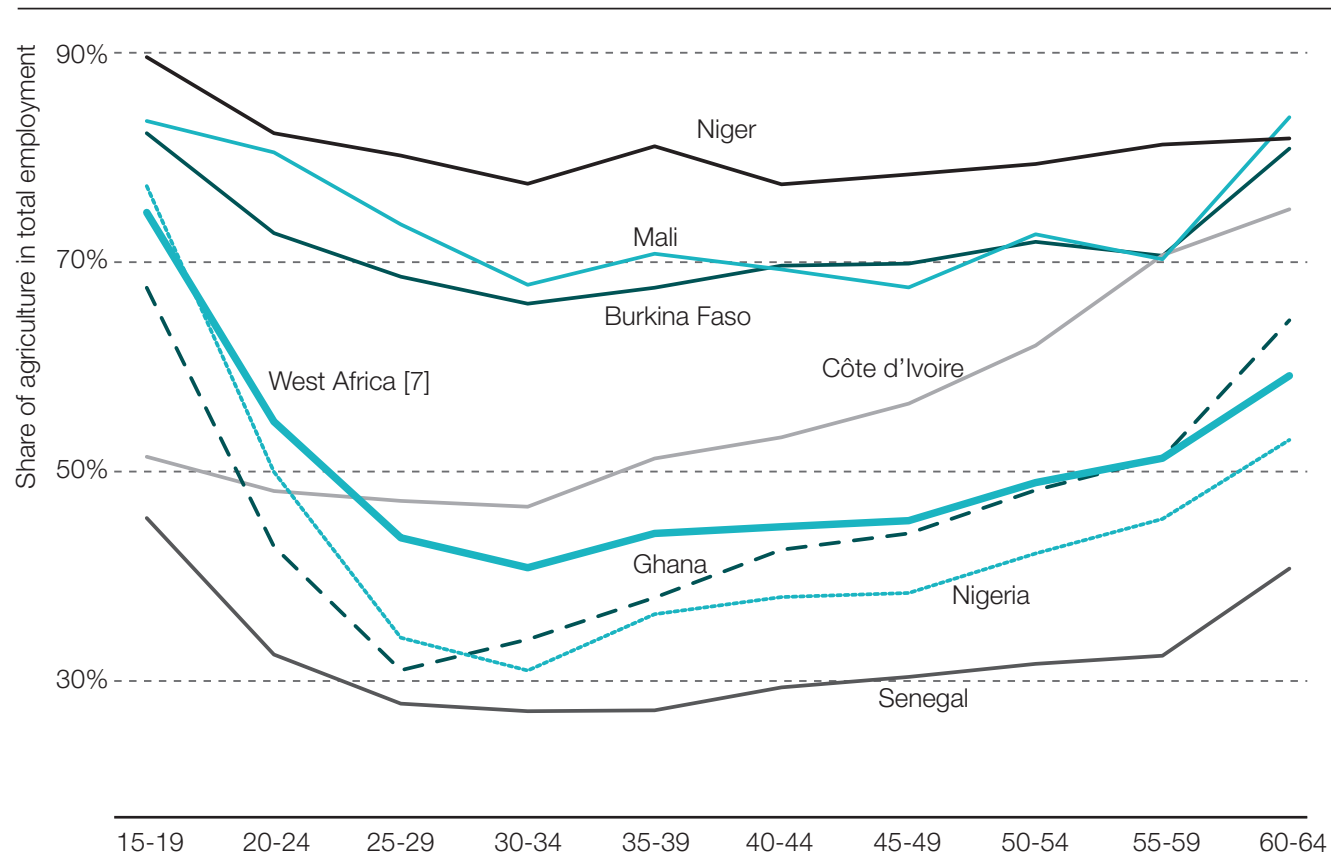

Source: Authors' calculations based on ANSD (2015), World Bank (2017a), INS (2012).

The decrease in the share of agricultural employment is accompanied by increases in employment in the off-farm activities of the food system and in the non-food system (Figure 9). In Côte d'Ivoire, Ghana, Nigeria and Senegal, the employment share outside agriculture for the 15-19 and 30-34 age cohorts increases from 31\% to 67\% (within total employment). For the same age cohorts in Burkina Faso, Mali and Niger, the employment share outside agriculture increases from $17 \%$ to $31 \%$. The youth transition into non-agricultural activities is taking place more rapidly and in greater numbers than for older generations, partly due to youth having higher levels of education and being more mobile (Christaensen, 2017). In addition, lack of access to productive agricultural resources and aspirational aspects are factors which push youth out of agriculture.

Employment patterns for 20-24 year olds in the food economy mirror trends in the total working age population. However, youth can play an important role in the development of food economy activities, including agriculture. The transformations in the food economy mean that greater skills and education are necessary to access employment opportunities and develop activities (Jayne et. al., 2014). For instance, data for Senegal shows that when youth are heads of agricultural production units, they are strongly involved in producer organisations and co-operatives, as well as credit and water usage associations (IPAR, 2015). Equipping youth with the skills and education needed and reducing barriers to productive resources, which are significantly higher for youth and young women in particular, will promote employment potential and diversification. 
Figure 9

Youth transition into the workforce

a) Côte d'Ivoire, Ghana, Nigeria, Senegal

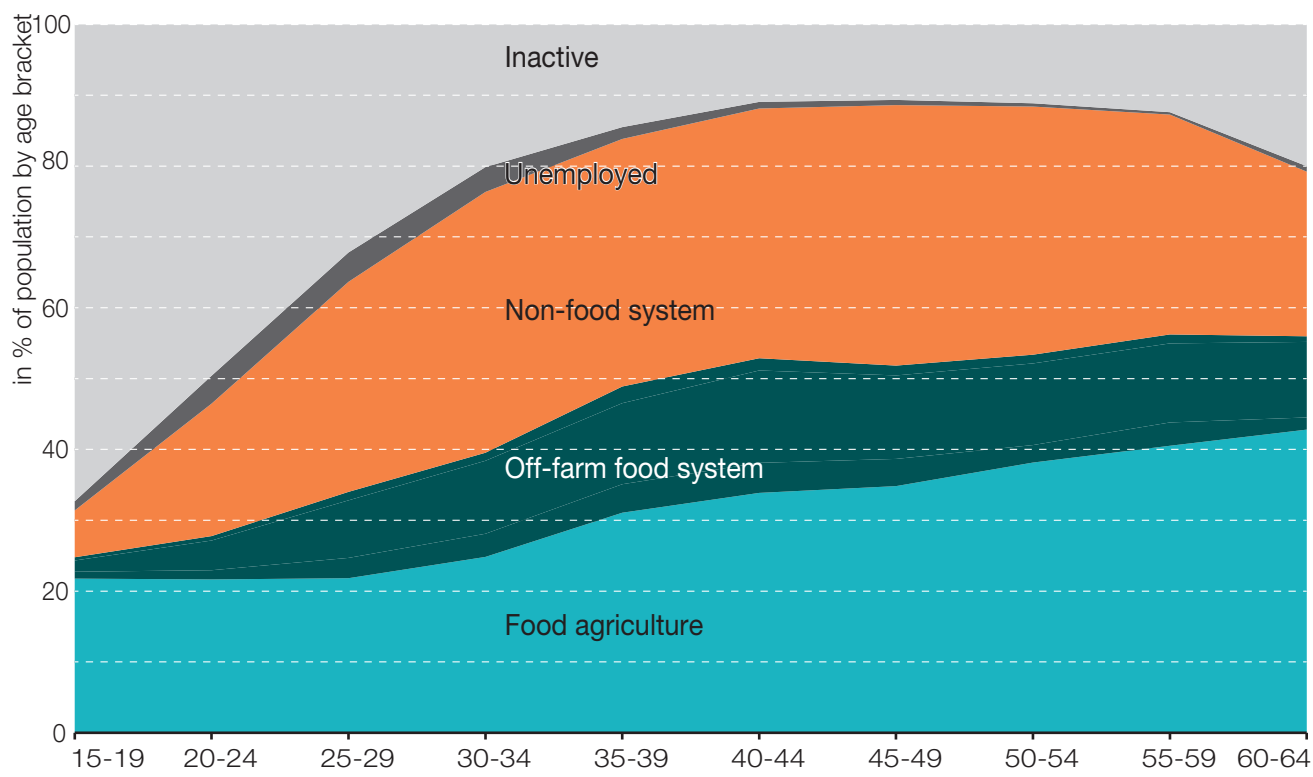

b) Burkina Faso, Mali, Niger

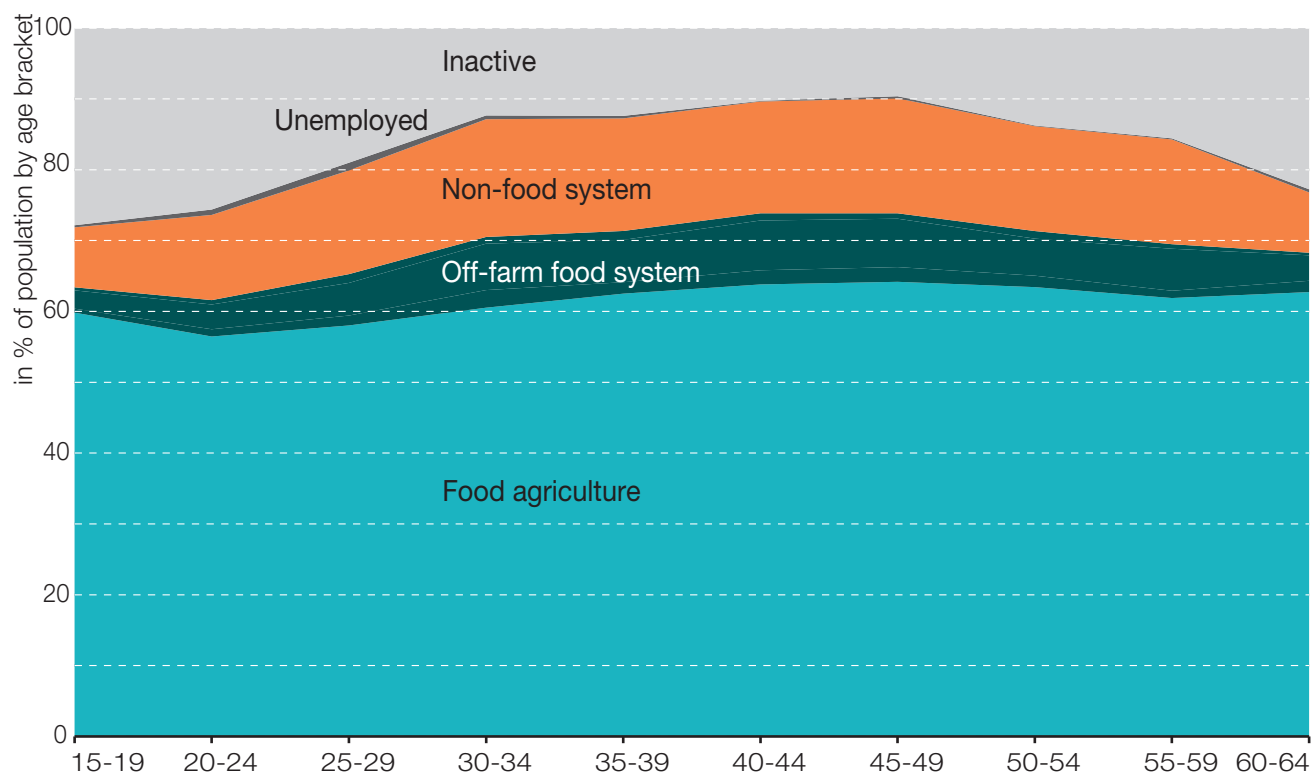

Source: Authors' calculations based on ANSD (2015), World Bank (2017a), INS (2012).

\section{Food economy employment and women}

The food economy plays a particularly important role for female employment. Sixty-eight percent of all employed women work in the food economy. Although women account for only a slightly higher share of total food system employment, contributing $51 \%$ of all employed, they dominate employment in the off-farm segments. Women account for $88 \%$ of total food-away-from-home employment, 83\% of total food manufacturing employment and $72 \%$ of total food marketing employment (Figure 10). Off-farm food system activities are thus particularly important in providing job opportunities for women. Overall, 37\% of all female food economy workers are employed in off-farm segments compared to $11 \%$ of men. 
Figure 10

Share of women's employment by food segment

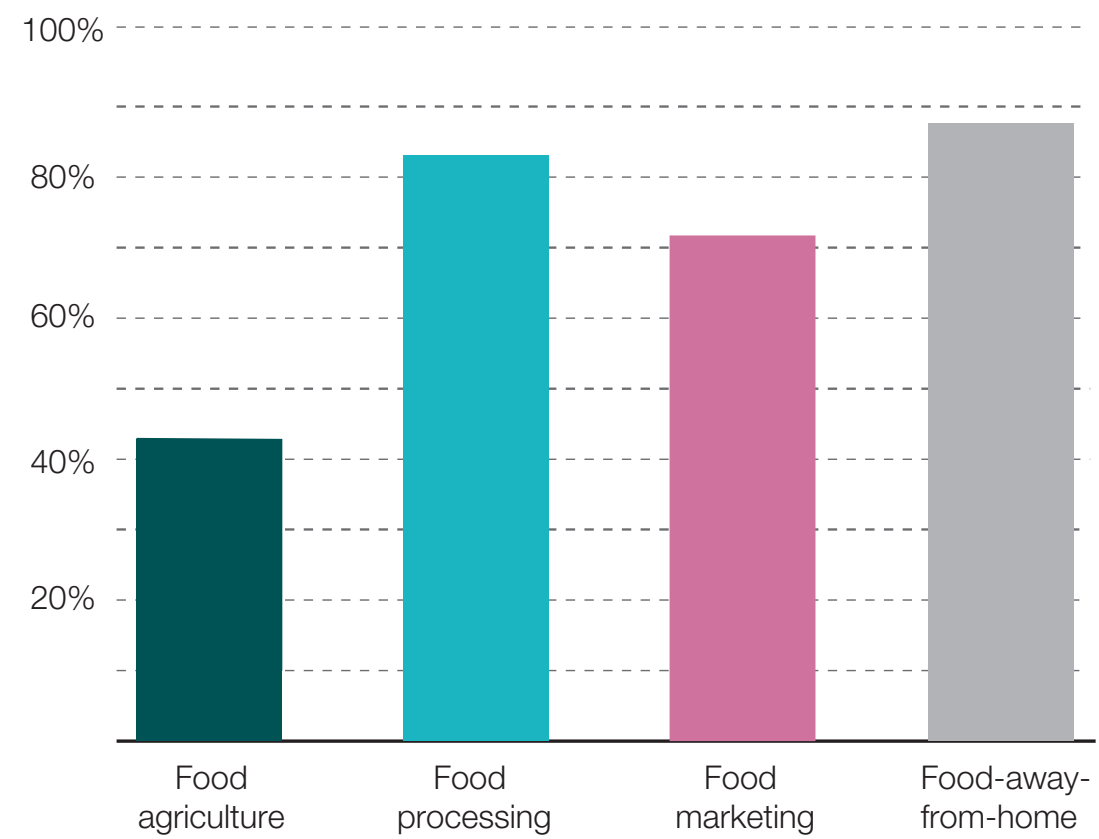

Source: Authors' calculations based on ANSD (2015), World Bank (2017a), INS (2012).

In rural areas, $75 \%$ of female employment within the food economy is in agriculture. However, women are significantly less likely to be heads of agricultural production units than men; they have less access to higher value land (in terms of equipment such as irrigation or land conditions) and usually have smaller farms (IPAR, 2015). Gender differences in access to productive resources and social norms and perceptions that encourage or discourage women's engagement in certain activities, lead women to invest in niche activities where entry barriers are less rigid (IPAR, 2015). Food processing and food services are almost exclusively women-led activities in rural areas. Overall, women are four times more likely to work in off-farm segments in rural areas than men.

Table 4

Share of women's employment in the food economy

\begin{tabular}{|c|c|c|c|c|c|}
\hline & $\begin{array}{l}\text { Total food } \\
\text { economy }\end{array}$ & $\begin{array}{l}\text { Food } \\
\text { agriculture }\end{array}$ & $\begin{array}{l}\text { Food } \\
\text { processing }\end{array}$ & $\begin{array}{l}\text { Food } \\
\text { marketing }\end{array}$ & $\begin{array}{l}\text { Food-away- } \\
\text { from-home }\end{array}$ \\
\hline Ghana & $58 \%$ & $49 \%$ & $77 \%$ & $84 \%$ & $92 \%$ \\
\hline Burkina Faso & $56 \%$ & $54 \%$ & $79 \%$ & $71 \%$ & $82 \%$ \\
\hline West Africa (7) & $51 \%$ & $43 \%$ & $83 \%$ & $72 \%$ & $88 \%$ \\
\hline Mali & $50 \%$ & $49 \%$ & $62 \%$ & $66 \%$ & $51 \%$ \\
\hline Nigeria & $50 \%$ & $37 \%$ & $87 \%$ & $72 \%$ & $92 \%$ \\
\hline Niger & $49 \%$ & $47 \%$ & $84 \%$ & $59 \%$ & $93 \%$ \\
\hline Cote d'ivoire & $48 \%$ & $43 \%$ & $30 \%$ & $71 \%$ & $71 \%$ \\
\hline Senegal & $37 \%$ & $36 \%$ & $25 \%$ & $33 \%$ & $77 \%$ \\
\hline
\end{tabular}

Note: Cell colouring based on conditional formatting, darker colours reflect higher cell values. First column formatting conditioned on column values; values in column 2, 3, 4, 5 conditional formatting on row values.

Sources: Authors' calculations based on ANSD (2015), World Bank (2017a), INS (2012). 
In urban areas, off-farm food activities account for one out of three jobs for women (one out of seven for men). This share is even higher in Niger, Burkina Faso and Ghana, reaching 1 out of 2 jobs in Niger. These activities can be highly profitable sources of income. Urban food processing and food-away-from-home services, in particular, are growing and lucrative activities. In the Attécoubé district of Abidjan, (Côte d'Ivoire), 20\% of the population is engaged in attiéké processing. The processors are mainly women who earn on average 30\% to 50\% more than in many other professions (ex. hairdressers, mechanics, upholsterers) and 85\% of them belong either to middle- or upper-income groups (MADR/ Côte d'Ivoire, 2015).

Yet, women rarely have access to the resources needed to develop their activities in relation to their potential and ambitions. Private sector institutions, like banks, are poorly informed about the potential of small- and medium-sized food processing enterprises and do not provide funding. Public policies and strategies pay too little attention and resources to these segments, despite their importance in food economy development (Staatz et. al., 2016). Current conditions and obstacles to women's economic participation vary across countries and within countries, depending on specific value chains, trade network structures, barriers to mobility, etc. (Bouchama et al., 2018). However, policies and investments that tackle gender specific constraints and promote off-farm food economy segments could have a particularly large impact on women's economic activities and food economy development.

\section{ECONOMIC AND SPATIAL DIMENSIONS OF FOOD EMPLOYMENT}

$\mathrm{T}$

he transformation of food systems creates new employment opportunities in on- and off- farm activities and in rural and urban areas. Rural areas will particularly benefit. Countries such as Vietnam, that have successfully transformed agriculture and rural economies in response to Bennett's Law have historically experienced the fastest decline in rural poverty (Christiaensen and Premand, 2017). However, an important aspect to acknowledge is that the links between food economy activities (food value chains), which provide the connection between production and final consumption, also reflect the links between rural and urban areas. These spatial linkages across the rural-urban space, between rural areas and small towns and secondary cities, are important elements in food economy development and rural transformation and need to be better understood in order to develop employment opportunities.

\section{Food value chains and off-farm food economy employment}

Food value chains are a key driver in the development of diversified local rural economies and will provide an important share of off-farm (rural) labour demand. The dietary transformations that drive new labour demand on the farm, in the production of protein-rich food products (dairy, meat) and higher-value fruits and vegetables, are also increasingly driving off-farm labour demand in value chain activities in storage, transport, processing, packaging, wholesale and retail (Reardon, 2015).

Increasing agricultural productivity will be crucial in developing off-farm employment opportunities, as well as agriculture itself. Agriculture will continue to provide significant numbers of new jobs in the food economy over the coming decades (Tschirley et.al., 2016). Productivity increases are equally important in generating demand for off-farm activities (Box 1). Recent analyses (Christiaensen and Premand, 2017; Jayne et. al., 2014; IPAR, 2014) show that rising farm productivity and farm income are among the main factors 'pulling' rural labour out of agriculture and stimulating a vibrant rural non-farm sector. 
$\underline{\text { Box } 1}$

Agricultural productivity and on- and off-farm labour demand in Senegal

The employment potential in agriculture has been underestimated in recent debates. This is partly attributable to an underestimation of local food demand and the capacity of local food production to supply these growing markets, combined with an overestimation of imports (Allen and Heinrigs, 2016). Another dominant argument is the perceived low labour productivity in agriculture and therefore the absence of productive employment opportunities. However, recent evidence (McCullough, 2017 and Christiaensen and Premand, 2017) suggests that productivity differences between agriculture and secondary and tertiary activities are significantly smaller than usually assumed (rather in the order of $1: 2$ than $1: 6$ ). Also, there is strong heterogeneity in labour productivity within agriculture, demonstrating the potential for increasing intrasectoral productivity under existing agro-ecological conditions. Data from Côte d'Ivoire shows, for instance, that average labour productivity in agriculture is highest in Abidjan and other urban areas (Christiaensen and Lawin, 2017). This heterogeneity reveals the importance of spatial factors and local context.

Part of the heterogeneity in agricultural productivity comes from underemployment. Data from Senegal (IPAR, 2015) comparing three rural areas show the impact of technology and market orientation on productivity and labour demand (Figure 11). The figure shows the strong differences in productivity between the three areas which are characterised by very different production systems. Labour productivity in the Niayes, where production is dominated by horticulture for urban markets, is 17 times greater than in the Groundnut Basin, characterised by rain-fed groundnut and millet production. Land productivity is 12 times greater. Yet during the rainy season the labour productivity gap between the Groundnut Basin and the Niayes region drops to a factor of three. The differences in productivity are strongly influenced by differences in activity levels. The IPAR study explains that "activity levels vary greatly depending on the period of the year (rainy season, off-season). The groundnut basin is characterised by high activity levels during the rainy season and low activity levels in the off-season. This is not surprising given the rain-fed production system. The Niayes shows relatively high activity levels during both periods." (IPAR, 2015). Higher productivity, driven by investments into more specialised and commercialised production systems is also increasing labour demand within agriculture, as in the case of the Delta region which is characterised by intensive production of cereals and vegetables (rice, onion and tomato) using large-scale irrigation and mechanical equipment. The share of farms hiring labour in the Delta is double the share in the Niayes.

\section{Figure 11}

Agricultural productivity and labour demand in Senegal

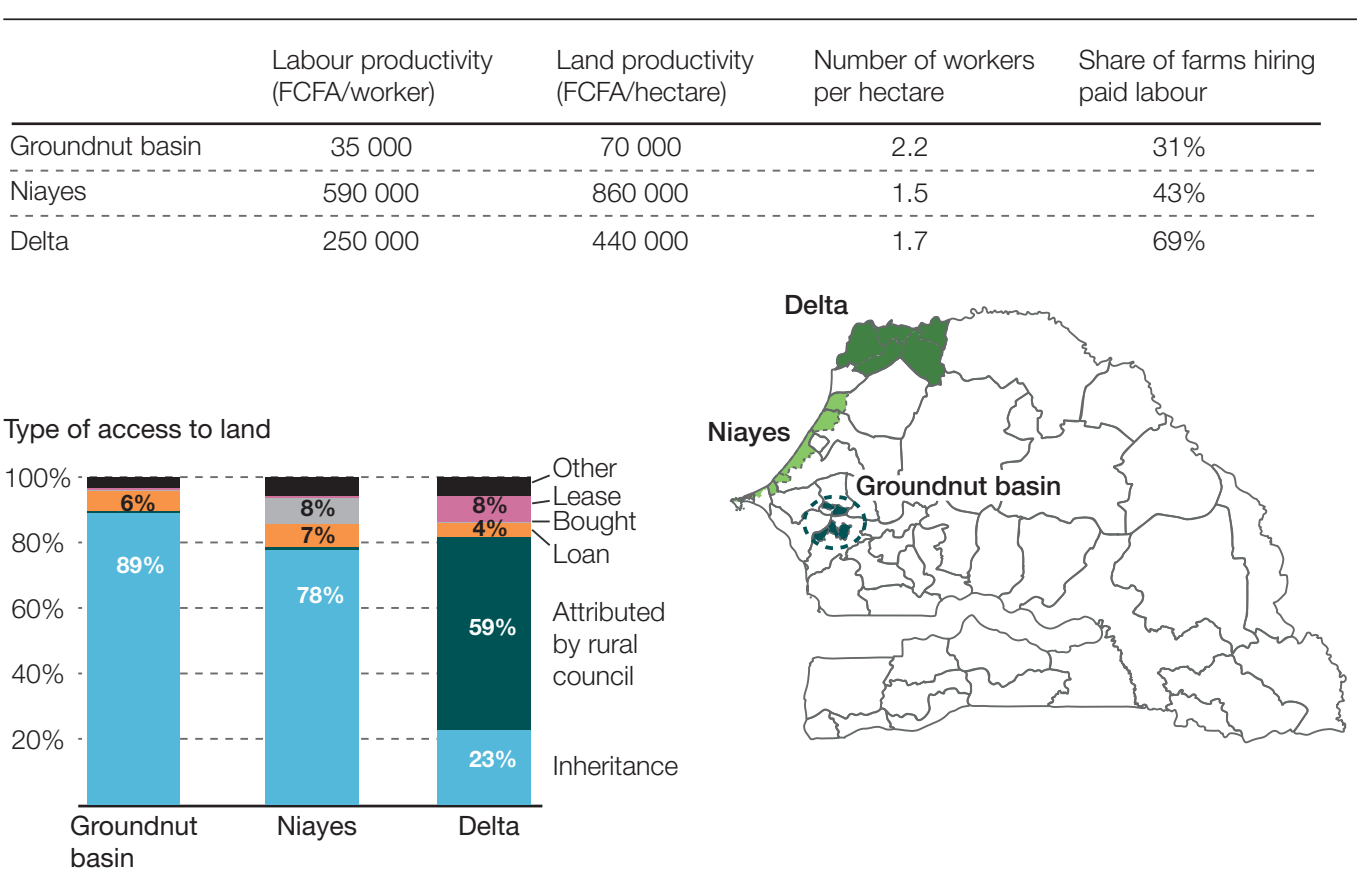

Note: CFA franc (FCFA).

Source: Authors' calculation based on IPAR (2015), «Emploi et migration des jeunes en Afrique de l'Ouest - Rapport final Sénégal », http://www.ipar.sn. 
Many of the new off-farm jobs in food value chains are linked to agriculture. A productive agricultural sector is the basis for competitive food value chains and creating demand for rural off-farm activities. These rural off-farm activities are primarily in the food processing segment of the food economy, such as basic cleaning, grading and packaging (first stage processing) and in the food marketing segment, such as warehousing, transportation, wholesaling and retailing. Clearly, availability and access to infrastructure such as markets, storage and logistics infrastructure, electricity and roads, are essential. Yet a conducive agribusiness environment is equally important. This includes markets for productive resources, such as land and finance, well-organised value chain actors, access to information (e.g. markets, prices, quality standards and norms) and extension support services, and availability of skilled labour, among others. Attractive locations will also increase demand for related services in input and output markets, including agro-dealers for agricultural machinery and tools, seeds and planting material and packaging material suppliers, further creating new employment opportunities to drive the local economy (Proctor and Berdegué, 2016). Given the food demand projections for West Africa (and Africa overall) (Allen and Heinrigs, 2016), the potential for new jobs in food value chains is enormous. Developing this potential will help to answer the African employment challenge.

The employment opportunities in food value chains, including in farming, require skill sets that are rapidly evolving. These include knowing how to use improved technologies (seeds, fertilisers, conservation practices) and information and communications technologies (ICTs) for accessing market information, as well as how to navigate public and private service institutions such as finance, extension support and marketing services (Jayne et. al., 2014). Anticipating and supporting these educational requirements are of major importance to the jobs agenda.

\section{Spatial dimensions and rural-urban linkages}

Changes in the food system are also increasing the importance of territorial dimensions, in particular rural-urban linkages. The spatial intensity of interactions between urban and rural areas has significantly increased with urbanisation and the growing role of markets in accessing food. These spatial interactions, which include the physical movement of goods and people, are shaping the scale and number of the different actors and activities involved in food value chains, impacting local labour markets. Such spatial patterns, observable in most countries of the world, are not static and change with development, urbanisation and connectivity (Berdegué et. al., 2014; Prieto Curiel et. al., 2017).

Looking at rural employment by administrative sub-division rather than at country level highlights the large spatial heterogeneity in rural employment diversification. In southern Côte d'Ivoire and Ghana, for instance, rural areas that are in proximity to the main urban agglomerations are more diversified. In Mali, communes along the Niger River show the highest employment diversification. In Nigeria, in 99 out of the 299 Local Government Areas covered, agricultural employment accounts for less than $50 \%$ of total employment (Map 1).

Proximity to markets matters for developing diversified rural economies (Proctor and Berdegué, 2016; OECD/SWAC, 2013; Dorosh et.al., 2010). Rural areas connected to output and input markets and with specialised agricultural production offer productive off-farm opportunities in the downstream segments of agricultural value chains. The differences in local availability and accessibility to food value chain infrastructure and services (including collection hubs, processing, grading and storage facilities, transport and logistics infrastructures in terms of wholesale and retail market structures, and more broadly in terms of input and output markets, including land and capital) affect local labour markets and skills demands. Recent micro-level evidence supports the influence that proximity to towns, markets and infrastructure has on rural non-farm employment shares and income (Jayne et.al. 2014). ${ }^{12}$ 


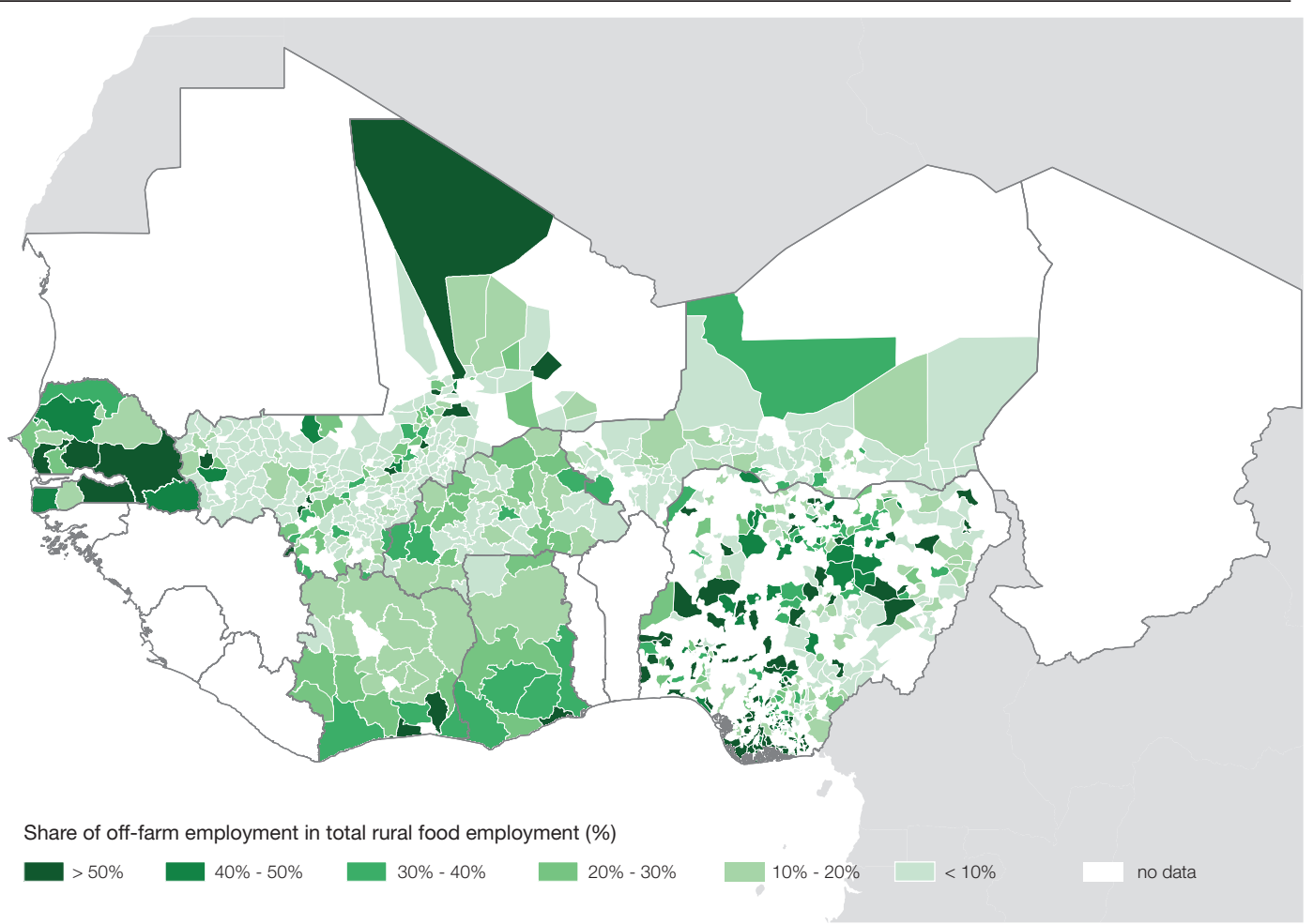

Source: Authors' calculations based on ANSD (2015), World Bank (2017a), INS (2012).

Small towns and intermediate cities and will play an important role in the development of the food economy. For the vast majority of family farms, the entry points to the food economy are the region's small towns and secondary cities. It is often in small urban centres where the growth and consolidation of off-farm activities and employment in the food economy occurs (Tacoli and Agergaard, 2017; Proctor and Berdegué, 2016). Access to these off-farm employment opportunities in rural areas and small towns is especially important for better and more inclusive employment (Christiaensen and Lawin, 2017).

Creating forward and backward linkages between the rural sector and small- and mediumsized cities are of particular importance in developing employment opportunities outside of major cities (Henderson and McNamara, 2000; Proctor and Berdegué, 2016). Strengthening rural-urban connectivity through the provision of infrastructure; basic public and private services such as education, technical and vocational training; agricultural and food extension services; advisory and financial services and efficient market and logistics infrastructure in small- and medium-sized towns, are central to building diversified and vibrant local economies (Proctor and Bedegué, 2016). 


\section{POLICY CONSIDERATIONS}

The food economy is the largest employer in the region and its potential will continue to increase with population growth, urbanisation and income growth. Agricultural employment still accounts for the majority of food economy jobs and an important question is how this sector will evolve. There is potential to increase agricultural productivity and to provide for decent livelihoods. Key issues in the agricultural jobs agenda include identifying where this potential is highest and why, how obstacles to entry for women and youth can be removed and determining the projections for labour's exit from agriculture. This last point is linked to issues such as land availability and farm size, rural transformations, rural employment diversification and broader structural transformations.

Off-farm activities carry a particular importance in the food employment agenda. In many rural areas most off-farm jobs are in the food economy and are major sources of employment and income diversification. Promoting non-agricultural employment will depend on supporting private enterprises, in particular SMEs, to drive growth and job creation. Policies aimed at supporting value chain development, integrated skills development and systems as well as improving the overall business climate are needed. Another important aspect is that women dominate employment in off-farm segments, accounting for more than $75 \%$ of total employed. Policies and investments promoting off-farm food economy activities will have a particularly large impact on women. Yet little attention is give to these activities in many agriculture and food policies.

The analysis in this paper ilustrates the strong spatial heterogeneity in West Africa. Not all rural and rural-urban areas are equally integrated into the food system nor do they face the same constraints in developing more diversified local economies. Rural-rural migration, and mobility more broadly, should figure among the policy levers of employment strategies. However, there is a general lack of analyses and detailed data available on labour markets, and in particular on the spatial aspects that would allow for such territorial analyses. This absence of data hinders the study of labour market dynamics in the region and limits the capacity of governments and policy makers to anticipate future transformations and to inform employment policies at local and national levels.

\section{NOTES}

1 See Annex 1 for information on databases used and standardisation of activity codes.

2 The authors are grateful to David Tschirley for sharing the stata code used for the 2016 Tschirley et al. paper.

3 Tschirley et al. (2016) adopt a larger definition of the agro-food system, which include also production, processing and retail of agricultural raw material not intended for human consumption, such as cotton.

4 Annex 2 provides details on modelling.

5 One possible reason could be that the 2009 population census provides urbanisation figures according to two different definitions of urban.

6 Agricultural labour involved in the production of cotton is counted in agricultural employment, but excluded from employment in «food agriculture» since it is not part of the food system.

7 The $8 \%$ import share refers to the share of the value of total extra-regional food imports in total household food expenditure. The way of expressing food imports as share of total value created in the domestic food economy (household food expenditure) compares the diversity of food imports, ranging from raw, or lightly processed, agricultural products such as rice and wheat, to highly processed foods such a frozen fish and dairy products for example, that include value added outside agriculture - in the food economy.

8 FTE is defined as working 40 hours per week over 52 weeks a year.

9 "Visible" underemployment is often defined as working less than 40 hours per week.

10 Excluding beverages and food catering.

11 Data presented here are only available for the seven countries for which detailed employment data is available

(Burkina Faso, Côte d'Ivoire, Ghana, Mali, Niger, Nigeria, Senegal).

12 The other factors factors cited having a strong impact on rural non-farm diversification are agricultural productivity, education, family size and farm size (Jayne et.al., 2014) 


\section{REFERENCES}

Allen, T. and P. Heinrigs (2016), "Emerging Opportunities in the West African Food Economy", West African Papers, No. 01, OECD Publishing, Paris. http://dx.doi.org/10.1787/5jlvfj4968jb-en.

Bouchama, N., et al. (2018), "Gender Inequality in West African Social Institutions", West African Papers, No. 13, OECD Publishing, Paris, http://dx.doi.org/10.1787/fe5ea0ca-en.

Bricas, N., C. Tchamda and F. Mouton (2016), « L'Afrique à la conquête de son marché alimentaire intérieur. Enseignements de dix ans d'enquêtes auprès des ménages d'Afrique de l'Ouest, du Cameroun et du Tchad ", Etudes de l'AFD, No. 12, Agence française de développement, Paris, http://www.afd.fr/.

Christiaensen, L. (2017), "Agriculture in Africa - Telling myths from facts: A synthesis", Food Policy, vol. 67, pp. 1-11, Elsevier, Amsterdam, https://doi.org/10.1016/j.foodpol.2017.02.002.

Christiaensen, L. and G. Lawin (2017), "Jobs within the Structural Transformation - Insights for Côte d'Ivoire", in Côte d'Ivoire Jobs Diagnostic - Employment, Productivity, and Inclusion for Poverty Reduction, Christiaensen, L. and P. Premand (eds), World Bank, Washington, DC, http:// documents.worldbank.org.

Christiaensen, L. and P. Premand (eds) (2017), Côte d'Ivoire Jobs Diagnostic - Employment, Productivity, and Inclusion for Poverty Reduction, World Bank, Washington, DC, http:// documents.worldbank.org.

Dorosh, P. et al. (2010), "Crop production and road connectivity in sub-Saharan Africa. A spatial analysis". Policy Research Working Paper, No. 5385, Africa Region Sustainable Development Division, World Bank, Washington DC, http://documents.worldbank.org/curated/ en/319731468006253963/pdf/WPS5835.pdf.

Hebous, S. and TT. Tran (2017), "Trends and Prospects for Formal Job Creation in Côte d'Ivoire", in Côte d'Ivoire Jobs Diagnostic - Employment, Productivity, and Inclusion for Poverty Reduction, Christiaensen, L. and P. Premand (eds), World Bank, Washington DC, http://documents. worldbank.org

Henderson, J. R. and K.T. McNamara (2000), "The location of food manufacturing plant investments in Corn Belt counties", Journal of Agricultural and Resource Economics, Vol 25, no. 2, pp. 680-697.

ILO (2012a), Sectoral country profil - Brazil, International Labour Organization, Geneva, http://www. ilo.org.

ILO (2012b), Sectoral country profil - South Africa, International Labour Organization, Geneva, http://www.ilo.org.

IPAR (2015), « Emploi et migration des jeunes en Afrique de l'Ouest - Rapport final Sénégal », IPAR, Dakar, http://www.ipar.sn.

Jayne T.S., J. Chamberlin and D.D. Headey (2014), "Land Pressures, the evolution of farming systems, and development strategies in Africa: A synthesis", Food Policy 48 (2014) 1-17, https:// doi.org/10.1016/j.foodpol.2014.05.014

Kuznets, S. (1966), Modern Economic Growth: Rate, Structure and Spread, Yale University Press, New Haven, CT.

MADR/Côte d'Ivoire (2015), «Enquête-test des outils pour l'intégration de la dimension 'revenu des ménages' dans le suivi de la vulnérabilité en zone urbaine en Côte d'Ivoire : Cas du Quartier Plateau de la Commune Attécoubé », Ministère de l'Agriculture et du Développement Rural, Abidjan

McCullough, B.E. (2017), "Labor productivity and employment gaps in Sub-Saharan Africa", Food Policy, Vol 67, Elsevier, Amsterdam, pp. 133-152, http://dx.doi.org/10.1016/j. foodpol.2016.09.013

Ministry of Food and Agriculture of Ghana (2016), "Pilot research-study on the integration of 'households income' in the monitoring of urban vulnerability in Ghana”, Statistics, Research and Information Directorate, Accra.

Nesheim, M.C., M. Oria et P.T. Yih (dir. pub.) (2015), "A Framework for Assessing Effects of the Food System", Committee on a Framework for Assessing the Health, Environmental, and Social Effects of the Food System, Food and Nutrition Board, Board on Agriculture and Natural Resources, Institute of Medicine, National Research Council, Washington, DC, National Academies Press, www.ncbi.nlm.nih.gov/books/NBK305168/.

OECD/SWAC (2018), Africapolis: Urbanisation dynamics in Africa 1950-2015, West African Studies, OECD Publishing, Paris (forthcoming).

OECD/SWAC (2013), Settlement, Market and Food Security, OECD Publishing, Paris. http://dx.doi. org/10.1787/9789264187443-en. 
Prieto Curiel, R., P. Heinrigs and I. Heo (2017), "Cities and Spatial Interactions in West Africa: A Clustering Analysis of the Local Interactions of Urban Agglomerations", West African Papers, No. 05, OECD Publishing, Paris. http://dx.doi.org/10.1787/57b30601-en.

Proctor, F. and J.A. Berdegué (2016), "Food systems at the rural-urban interface", Working Paper series, No. 194, Rimisp, Santiago, Chile.

Reardon, T. (2015), "The hidden middle: the quiet revolution in the midstream of agrifood value chains in developing countries", Oxford Review of Economic Policy, Vol. 31, No. 1, pp. 45-63, https://doi.org/10.1093/oxrep/grv011.

Reardon, T. et al. (2015), "Urbanization, Diet Change, \& Transformation of the Downstream and Midstream of the Agrifood System: Effects on the Poor in Africa and Asia", Faith \& Economics, Vol. 66, pp. 43-63, http://www.gordon.edu/ace/pdf/2015\%20Fall\%20-\%20Reardon.pdf.

Republic of Ghana, Ministry of Food and Agriculture, Statistics, research and information Directorate, (2016), "Pilot research-study on the integration of 'households income' in the monitoring of urban vulnerability in Ghana".

Staatz, J. and F. Hollinger (2016), "West African Food Systems and Changing Consumer Demands", West African Papers, No. 04, OECD Publishing, Paris. http://dx.doi.org/10.1787/b165522b-en.

Tacoli, C and J. Agergaard (2017), Urbanisation, rural transformations and food systems: the role of small towns, IIED, London, ISBN: 978-1-78431-418-7.

Tschirley, D., M. Kondo and J. Snyder (2016), “Downstream report”, in Agri-food Youth Employment and Engagement Study (AGYEES), Allen, A., J. Howard, A. Jamison, T. Jayne, M. Kondo, J. Snyder, D. Tschirley and F. K. Yeboah (eds), Michigan State University, East Lansing, Michigan, http://www.isp.msu.edu.

\section{Databases}

ANSD (2015), Enquête nationale sur l'emploi 2015, Agence nationale de la statistique et de la démographie (ANSD), Senegal (database). http://anads.ansd.sn/index.php/catalog/92 (accessed on 01/09/2017).

World Bank (2017), Living Standards Measurement Survey (LSMS), World Bank (database). http:// microdata.worldbank.org/index.php/catalog/lsms (accessed on 01/09/2017)

World Bank (2017), World Development Indicators (WDI), World Dank (database http://databank. worldbank.org/data/reports.aspx?source=World\%20Development\%20Indicators (accessed on 01/09/2017)

INS (2012), Enquête nationale sur la situation de l'emploi 2012, Institut national de la statistique (INS), Côte d'Ivoire (database). http://www.ins.ci/n/nada/index.php/catalog/78/get_microdata (accessed on 01/09/2017).

ILO (2017), « Employment by sector », ILOSTAT, International labour Organization (ILO) (database). http://www.ilo.org/ilostat/faces/oracle/webcenter/portalapp/pagehierarchy/ Page3.jspx?locale=fr\&_afrLoop=1901062925392086\#!\%40\%40\%3Flocale\%3Dfr\%26_ afrLoop\%3D1901062925392086\%26_adf.ctrl-state\%3D81g6pxny5_103 (accessed on 01/09/2017). 


\section{ANNEX 1: DATA SOURCES AND STANDARDISATION}

\section{Data sources}

icroeconomic household data are available for seven countries (Burkina Faso,

Côte d'Ivoire, Ghana, Mali, Niger, Nigeria and Senegal). In five of these (Burkina Faso, Ghana, Mali, Niger and Nigeria), the World Bank's Living Standards Measurement Study (LSMS) household panel surveys were used. ${ }^{1}$ More precisely, the Living Standards Measurement Study - Integrated Surveys on Agriculture² (LSMS-ISA) are used for four countries (Burkina Faso, Mali, Niger, and Nigeria). For Côte d'Ivoire and Senegal, the most recent available labour surveys were used.

Details and links to each of the seven databases used:

Burkina Faso: Enquête multisectorielle continue 2014

http://microdata.worldbank.org/index.php/catalog/2538

Côte d'Ivoire: Enquête nationale sur la situation de l'emploi 2012

http://www.ins.ci/n/nada/index.php/catalog/78/get_microdata

Ghana: Ghana Living Standards Survey 6 (With Labour Force Module) 2012-2013 http://www.statsghana.gov.gh/nada/index.php/catalog/72

Mali: Enquête agricole de conjoncture intégrée 2014

http://microdata.worldbank.org/index.php/catalog/2583

Niger: Enquête nationale sur les conditions de vie des ménages et l'agriculture 2014

http://microdata.worldbank.org/index.php/catalog/2676

Nigeria: General Household Survey 2012-2013

http://microdata.worldbank.org/index.php/catalog/1952

Senegal: Enquête nationale sur l'emploi 2015

http://anads.ansd.sn/index.php/catalog/92

\section{Standardisation}

Five different statistical classifications ${ }^{3}$ for economic activities are used across the seven surveys. Conversion tables have been produced to categorise each classification into a common nomenclature of food economy activities. These conversion tables are available upon request.

Identifying food system activities requires gathering information on activity at the lowest or second-lowest level of detail. This was not always possible, in particular for Nigeria where only the two-digit activity classification is available. To obtain food system estimates, Tschirley et al. (2017)'s imputation approach is implemented.

This approach uses food consumption budget shares in total expenditure, by urban and rural location, as parameters to allocate aggregated activities into food economy activities. For instance, employment in "non specified retail trade" activities in Burkina Faso is spread between food retail and non-food retail as a function of households' budget shares on food and non-food products. Data on consumption is from the World Bank Global Consumption Database. ${ }^{4}$

Two other parameters are used: i) the share of food agriculture employment in total agriculture employment in Nigeria is derived from Tschirley et al. (2017); and ii) the employment share of fibre crop (such as cotton) in total crop production in Côte d'Ivoire, which is estimated from expert knowledge. All parameters used are available upon request. 


\section{ANNEX 2: EMPLOYMENT MODELLING - TEN COUNTRIES}

$\mathrm{E}$ mployment in the food economy is directly observed from microeconomic survey data for seven countries. For the remaining 10 countries (Benin, Cabo Verde, Gambia, Guinea, Guinea-Bissau, Liberia, Mauritania, Sierra Leone, Chad and Togo), recent microeconomic data was not available. A two-step modelling approach was implemented to compute estimates for employment distribution within the food economy.

\section{Estimating food economy employment in agriculture}

The first step consists in estimating food economy employment in agriculture. Economic theory and empirical evidence show that there is a negative relationship between agriculture's shares in total value added and employment on the one hand, and GDP per capita, on the other hand (Kuznets, 1966). This phenomenon is commonly attributed to both the rapid development of new farming technologies, leading to improvements in yields and labour productivity, and the slower rise in the demand for food as compared with other goods and services. Engel's law establishes that households' demand for food increases less than proportionally as income increases. Structural change in the distribution of employment by sector is, in part, related to this negative relationship between income and food consumption shares.

Another robust empirical result in economics literature shows that there is a statistically significant relationship between income and expenditure shares spent on higher value foods. Bennett's law indicates that the composition of the food basket changes as income increases, with a more than proportional decline of starchy staple foods and a compensating increase of higher value food consumption. This suggests that there is a relationship between the distribution of value added and employment between segments within the food economy and income.

A strong correlation is observed between GDP per capita and share of agriculture in total food economy employment for the seven countries (Figure A2.1). This result does not establish any formal economic relationship between these two variables, but it provides a statistical regularity in the case of West Africa that allows the formulation of assumptions for the ten countries with no detailed employment data. It is assumed in this paper that the shares of agriculture in food economy employment for these ten countries are ordered following the relationship observed for the other seven countries.

\section{Estimating off-farm food system employment}

In a second step, employment shares in the three off-farm segments of the food economy are estimated. It is observed that, with the exception of Cote d'Ivoire, there is an almost constant relationship between the food processing, food marketing and food-away-fromhome (FAFH) segments (Table A2.1), in which employment in food marketing and FAFH represents four times the employment in food processing. As a result, the simple average reported for six countries (Côte d'Ivoire excluded) over the three segments is used to impute off-farm employment distribution for the ten remaining countries.

To recover numbers from computed shares, ILO data on employment by sector ${ }^{5}$ is used. It is observed that employment in the agriculture segment of the food economy across the seven countries represents between $97 \%$ and $99 \%$ of primary sector employment. A simple average of this share - combined with ILO data on employment in the primary sector - is used to estimate the number of persons employed in food agriculture for each of the ten countries. Figures for the other three segments are arithmetically computed from the modelled shares as described above. 
Figure A2.1

Share of agriculture in total food economy employment and GDP per capita

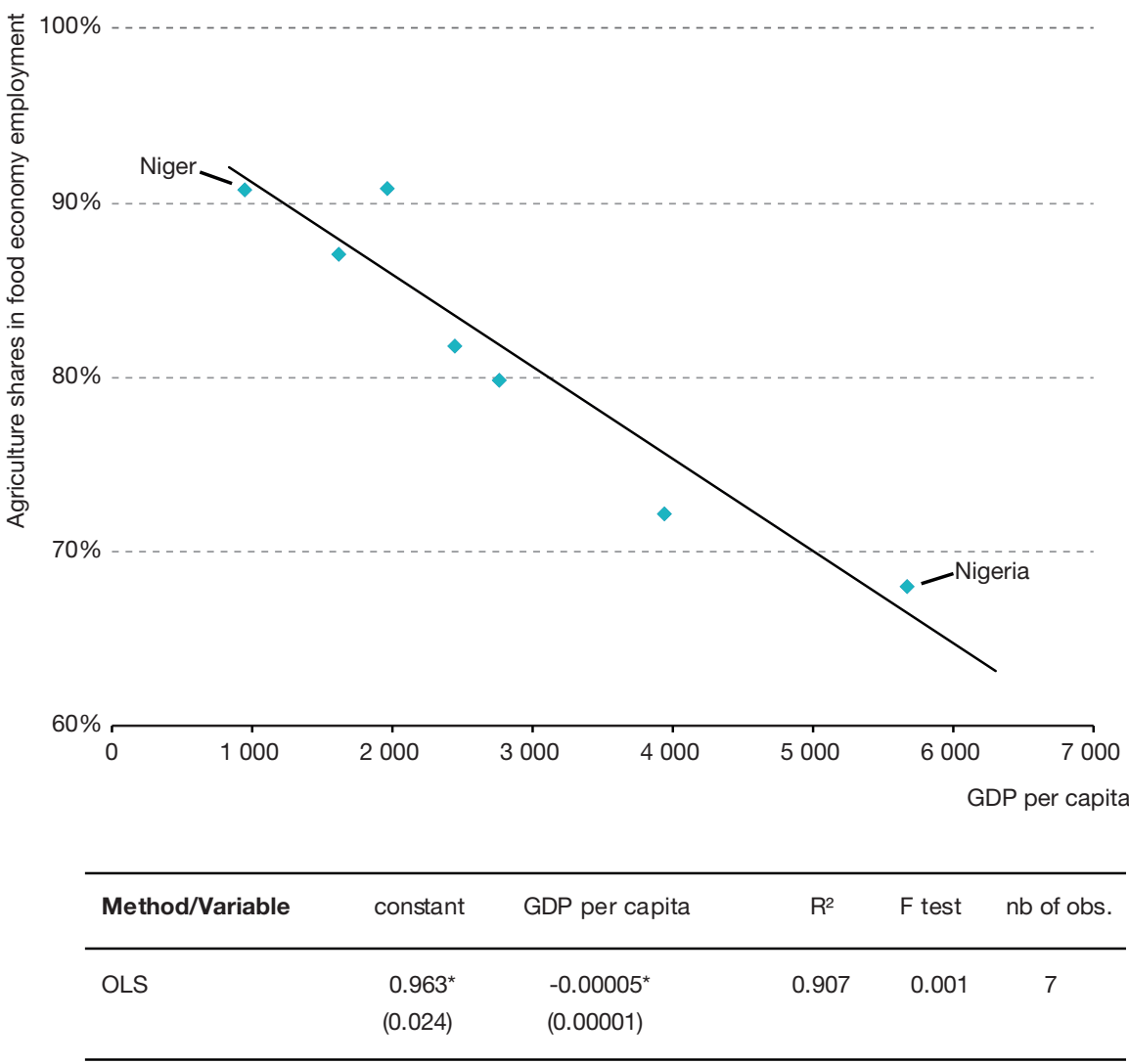

Note: Dependent variable is the agriculture share in food economy employment observed for seven countries. Estimation is Ordinary Least Squares (OLS). Standards errors are in parentheses. Significance at the $1 \%$ level is denoted respectively by *

Sources: Authors' calculations based on ANSD (2015), World Bank (2017a), INS (2012).

Table A2.1

Off-farm food economy segment employment shares

\begin{tabular}{lccc}
\hline & $\begin{array}{c}\text { Food } \\
\text { processing }\end{array}$ & $\begin{array}{c}\text { Food marketing } \\
\text { and FAFH }\end{array}$ & Ratio \\
\hline Burkina Faso & $2 \%$ & $11 \%$ & 5.0 \\
Côte d'Ivoire & $1 \%$ & $14 \%$ & - \\
Ghana & $6 \%$ & $22 \%$ & 3.7 \\
Mali & $2 \%$ & $7 \%$ & 4.6 \\
Niger & $3 \%$ & $7 \%$ & 2.5 \\
Nigeria & $7 \%$ & $25 \%$ & 3.3 \\
Senegal & $3 \%$ & $17 \%$ & 5.3 \\
\hline
\end{tabular}

Sources: Authors' calculations based on ANSD (2015), World Bank (2017a), INS (2012). 


\section{NOTES}

1 LSMS is a World Bank programme focused on generating high-quality household survey data, improving survey methods

and building capacity. http://econ.worldbank.org/WBSITE/EXTERNAL/EXTDEC/EXTRESEARCH/ EXTLSMS/0,,contentMDK:2350665w6 pagePK:64168445 piPK:64168309 theSitePK:3358997,00.html

2 LSMS-ISA aims to foster innovation and efficiency in statistical research on the links between agriculture and poverty reduction

in the region. http://econ.worldbank.org/WBSITE/EXTERNAL/EXTDEC/EXTRESEARCH/

EXTLSMS/0,,contentMDK:23512006 pagePK:64168445 piPK:64168309 theSitePK:3358997,00.html

3 International Standard Industry Classification (ISIC) revision 4 at the 4-digit level (Ghana), ISIC revision 4 at the 2-digit level (Nigeria), NAEMA initial nomenclature (Côte d'Ivoire), Nomenclature d'Activités des Etats Membres d'AFRISTAT (NAEMA) revision 1 (Senegal), and national nomenclature (Burkina Faso, Mali and Niger).

4 For more information: http://datatopics.worldbank.org/consumption/

5 Employment in primary, secondary and tertiary sectors is based on ISIC. The primary sector corresponds to tabulation category A (ISIC revision 4); it includes agriculture, hunting, forestry, and fishing. The secondary sector encompasses tabulation categories B-F (ISIC revision 4); it includes mining and quarrying (including oil production), manufacturing, construction, and public utilities (electricity, gas, and water). The tertiary sector corresponds to tabulation categories G-U (ISIC revision 4). It includes wholesale and retail trade and restaurants and hotels; transport, storage, and communications; financing, insurance, real estate, and business services; and community, social, and personal services. 


\section{ALSO IN THE WEST AFRICAN PAPERS SERIES:}

Allen, T. and P. Heinrigs (2016), “Emerging Opportunities in the West African Food Economy", http://dx.doi. org/10.1787/5jlvfj4968jb-en

Lewis, K. and C. Buontempo (2016), "Climate Impacts in the Sahel and West Africa: The Role of Climate Science in Policy Making", http://dx.doi.org/10.1787/5jlsmktwjcd0-en

Gnisci, D. (2016), “Women's Roles in the West African Food System: Implications and Prospects for Food Security and Resilience", http://dx.doi.org/10.1787/5jlpl4mh1hxn-en

Staatz, J. and F. Hollinger (2016), "West African Food Systems and Changing Consumer Demands", http://dx.doi.org/10.1787/b165522b-en

Prieto Curiel, R., P. Heinrigs and I. Heo (2017), “Cities and Spatial Interactions in West Africa: A Clustering Analysis of the Local Interactions of Urban Agglomerations", http://dx.doi.org/10.1787/57b30601-en

Walther, O. (2017), "Cross-border Co-operation Networks in West Africa", http://dx.doi.org/10.1787/73298292-en

Ibrahim, I.Y. (2017), “The Wave of Jihadist Insurgency in West Africa: Global Ideology, Local Context, Individual Motivations", http://dx.doi.org/10.1787/eb95c0a9-en

Allen, T. (2017), "The cost of high food prices in West Africa", http://dx.doi.org/10.1787/c2db143f-en

Van Den Hoek, J. (2017), “Agricultural market activity and Boko Haram attacks in northeastern Nigeria”, http://dx.doi. org/10.1787/13ba9f2e-en

Walther, O. (2017), "Wars and Conflicts in the Sahara-Sahel", http://dx.doi.org/10.1787/8bbc5813-en

Elisher, S. (2018), “Defying the Odds? Nigerien Responses to Foreign and Domestic Security Challenges", https://doi. org/10.1787/104d1c6d-en

Eizenga, D. (2018), “The Unstable Foundations of Political Stability in Chad", https://doi.org/10.1787/508844d3-en

Bouchama, N., et al. (2018), "Gender Inequality in West African Social Institutions", http://dx.doi.org/10.1787/fe5ea0ca-en

For more information on the series, please contact: lia.beyeler@oecd.org 